\title{
EphrinA5 Signaling Is Required for the Distinctive Targeting of Raphe Serotonin Neurons in the Forebrain
}

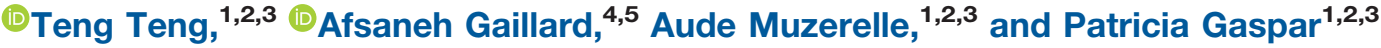

DOI:http://dx.doi.org/10.1523/ENEURO.0327-16.2017

${ }^{1}$ Inserm UMR-S 839, 75005, Paris, France, ${ }^{2}$ Université Pierre et Marie Curie, Paris, France, ${ }^{3}$ Institut du Fer à Moulin, Paris, France, ${ }^{4}$ Inserm 1084, Poitiers, France, and ${ }^{5}$ Université de Poitiers, Poitiers, France

\section{Visual Abstract}

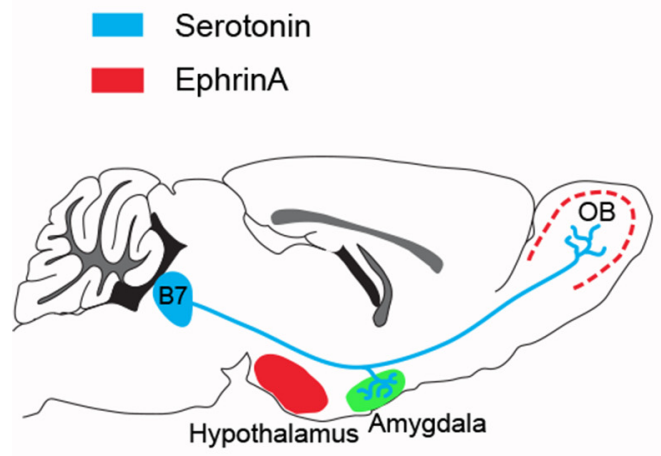

Control
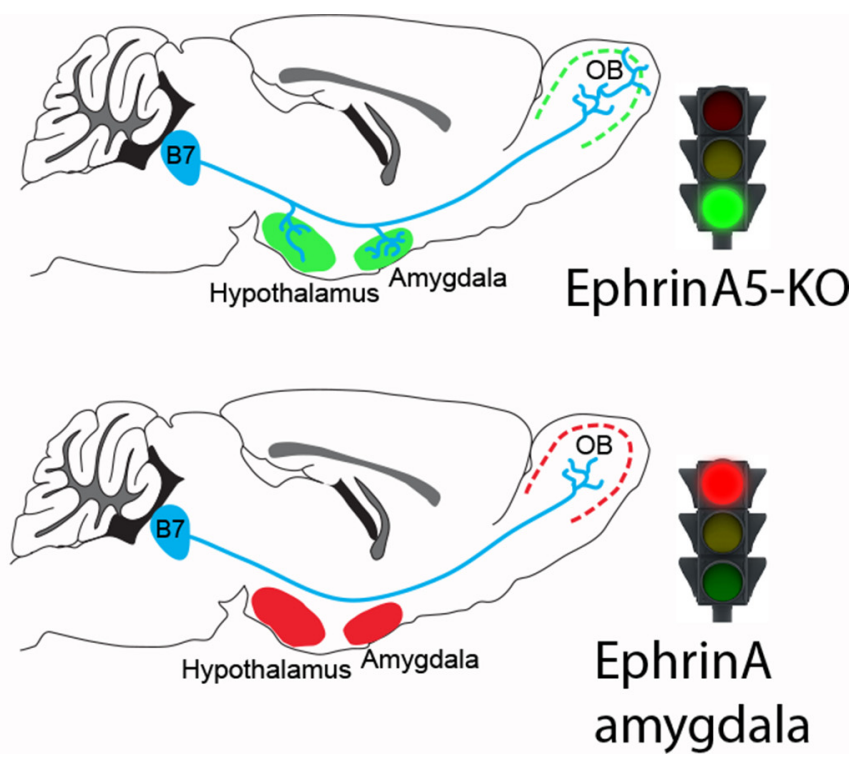

Serotonin (5-HT) neurotransmission in the brain relies on a widespread axon terminal network originating from the hindbrain raphe nuclei. These projections are topographically organized such that the dorsal (DR), and median raphe $(\mathrm{MnR})$ nuclei have different brain targets. However, the guidance molecules involved in this selective targeting in development are unknown. Here, we show the implication of ephrinA5 signaling in this process. We find that the EphA5 gene is selectively expressed in a subset of 5-HT neurons during embryonic and postnatal development. Highest coexpression of EphA5 and the 5-HT marker Tph2 is found in the DR, with lower

\section{Significance Statement}

This study shows for the first time the role of a guidance molecule for region-specific serotoninergic innervation. We establish that Eph-ephrinA signaling acts as a repulsive signal to target 5-HT axons originating from different raphe nuclei. EphA5 expression varies across raphe nuclei, correlating with different repulsive actions of ephrinA on 5-HT axons. EphrinA overexpression inhibits 5-HT innervation of the amygdala while EphrinA5 loss of function causes a mis-targeting of dorsal raphe 5-HT axons in the olfactory bulb and hypothalamus. This shows a new role of ephrinA signaling in 5-HT target selection and is likely to have important functional consequences. 
coexpression in the $\mathrm{MnR}$, and hardly any colocalization of the caudal raphe in the medulla. Accordingly, ephrinA induced a dose-dependent collapse response of 5-HT growth cones cultured from rostral but not caudal raphe. Ectopic expression of ephrinA3, after in utero electroporation in the amygdala and piriform cortex, repelled 5-HT raphe fiber ingrowth. Conversely, misplaced DR 5-HT axons were found in ephrin A5 knockout mice in brain regions that are normally only targeted by MnR 5- $\mathrm{HT}$ axons. This causes an overall increase in the density of 5-HT innervation in the ventromedial hypothalamus, the suprachiasmatic nucleus, and the olfactory bulb. All these brain areas have high expression of ephrinAs at the time of 5-HT fiber ingrowth. Present results show for the first time the role of a guidance molecule for the region-specific targeting of raphe neurons. This has important implications to understand how functional parsing of central 5-HT neurons is established during development.

Key words: amygdala; culture; Ephrin; hypothalamus; in utero electroporation; olfactory bulb

\section{Introduction}

Serotonin (5-hydroxytryptamine, 5-HT) neurotransmission is implicated in a large number of physiological functions, raising the question of a division of labor among the different hindbrain nuclei that synthesize 5-HT (Calizo et al., 2011; Hale and Lowry, 2011; Kiyasova and Gaspar, 2011). 5-HT-synthesizing neurons are distributed into several raphe nuclei in the hindbrain that have been parsed according to anatomical and physiological criteria. Individual raphe nuclei target different brain regions and, consequently, are involved in different functions. For instance, the caudal 5-HT raphe nuclei (B1-B3 cell groups), which are located in the medulla and project to the brainstem and spinal cord, are implicated in motor control and neurovegetative functions (Schmidt and Jordan, 2000; Pflieger et al., 2002; Brust et al., 2014). Conversely, 5-HT neurons of the rostral raphe, which are located in the pontine region of the hindbrain (B5-B9 cell groups) and project to the forebrain, have been involved in diverse higher brain functions, such as mood, learning, and social behaviors such as aggression and maternal behavior (Deakin and Graeff, 1991; Lucki, 1998; Trowbridge et al. 2011). Within these broad raphe divisions, further anatomical and functional distinctions can be made; for instance, the rostral raphe cluster comprises neurons of the dorsal raphe $(\mathrm{DR}=\mathrm{B} 6+\mathrm{B} 7)$ and the median raphe

Received December 9, 2016; accepted January 6, 2017; First published January 26, 2017.

The authors declare no competing financial interests.

Author contributions: T.T. and P.G. designed research; T.T. and A.M. performed research; T.T., A.G., and P.G. analyzed data; T.T. and P.G. wrote the paper; A.G. contributed unpublished reagents/analytic tools.

Dr Teng Teng was financed by the China Scholarsip Council; Research was supported by the Fondation de la Recherche Médicale, ERA-NET RESPOND and the Investissements d'Avenir program (ANR-11-0004-02), the Inserm, and the Université Pierre et Marie Curie. The team is part of the Ecole des Neurosciences de Paris training network and of the Bio-Psy Labex.

Acknowledgments: We thank Michael Reber for the primers and EphrinA3 construct and for his helpful advice on the manuscript. Imane Moutkine provided essential help for the molecular constructs and for qPCR analyses. Sebastian Brot and Yohan Bertelle are acknowledged for animal breeding, and the IFM imaging facility for advice. Alexandra Rebsam, Sophie Scotto, Anne Teissier, and Mariano Soiza Reilly contributed thoughtful remarks on the project and on the manuscript.

Correspondence should be addressed to Patricia Gaspar, INSERM U 839, 17 rue du Fer a Moulin, 75005, Paris, France. E-mail: patricia.gaspar@inserm.fr.

DOl:http://dx.doi.org/10.1523/ENEURO.0327-16.2017

Copyright (C) 2017 Teng et al.

This is an open-access article distributed under the terms of the Creative Commons Attribution 4.0 International, which permits unrestricted use, distribution and reproduction in any medium provided that the original work is properly attributed.
$(\mathrm{MnR}=\mathrm{B} 5+\mathrm{B} 8)$ groups that are implicated in different brain functions (Jacobs and Azmitia, 1992; Teissier et al., 2015; Fernandez et al., 2016) and innervate complementary targets in the telencephalon (Vertes et al., 1999; Muzerelle et al., 2016). This organization suggests that specific axon guidance molecules could orient the 5-HT-containing axons to specific targets, although the underlying molecular mechanisms are largely unknown (Kiyasova and Gaspar, 2011).

Previous transcriptome profiling of developing 5- $\mathrm{HT}$ raphe neurons identified distinct expression profiles between the rostral pontine and the caudal medullary raphe cell groups (Wylie et al., 2010). Among these differentially expressed genes, a number of axon guidance molecules, such as Eph receptors and their ephrin ligands, are potential candidates for the selective guidance of 5-HT neuron subsets. The properties of EphA receptors as shortrange guidance factors make them attractive candidates for selective axon targeting (O'Leary and Wilkinson, 1999; Klein and Kania, 2014). Eph-ephrin signaling has indeed been involved in many functions, one of the best known being its role in establishing topographic maps in several sensory systems (Prakash et al., 2000; Miko et al., 2007). Moreover, the EphA ligand, ephrinA5, was suggested to be involved in the development of the dopaminergic neurons, based on its dynamic developmental expression patterns (Deschamps et al., 2009, 2010; Cooper et al., 2009; Prestoz et al., 2012).

In the present study, we demonstrate a role for EphephrinA signaling in developing $5-\mathrm{HT}$ raphe neurons to repel axon growth of a subset of 5-HT neurons. We find that ephrinA5 is required for the exquisite differential targeting of the DR and MnR axons in the olfactory bulb, amygdala, and hypothalamus. These observations establish for the first time a role of Eph-ephrinA signaling to organize the broad topography of a monoaminergic system.

\section{Materials and Methods}

\section{Animals}

Most experiments (gene expression, cell cultures, electroporations) were performed on mice of the Swiss background (RjOrl:SWISS) purchased from a commercial breeder (Centre d'Elevage R. Janvier). Embryonic day 0 (E0) was defined as the plug date and postnatal day 0 (P0) as the date of birth. 
The Pet1-Cre::RCE-GFP mouse line was used for reverse-transcription qualitative PCR (RT-qPCR) analyses. ePet1-Cre mice (Scott et al., 2005) in which the serotonergic specific promoter of the Pet1 gene that controls Cre expression was crossed to the RCE-GFP mouse line where enhanced green fluorescent protein (eGFP) is conditionally expressed under the Rosa-26 promoter (Sousa et al., 2009). Pet1-Cre::RCE-GFP mice were bred in our local facility, and brains were collected from P5, P15, and adult mice.

The ephrinA5 knockout (KO) mouse line (Frisén et al., 1998) was maintained on a C57Black6 background (Deschamps et al., 2009). Briefly, these mice have a PGKneocassette replacing the $5^{\prime}$ acceptor splice site and the sequences encoding amino acid residues 42-129. The PCR primers for genotype are as follows: primer 1 (TCCAGCTGTGCAGTTCTCCAAAACA) and primer 2 (ATTCCAGAGGGGTGACTACCACATT) for wild-type sequences (397 bp) and primers 1 and 3 (AGCCCAGAAAGCGAAGGAGCAAAGC) for mutant sequences (513 bp).

All experiments were performed in compliance with the standard ethics guidelines (European Community Guidelines and French Agriculture and Forestry Ministry Guidelines for Handling Animals, decree 87849). All efforts were made to reduce the number of animals used and their suffering. Male and female mice were used indiscriminantly in all experiments.

\section{Histology}

Section preparation

Brains of Swiss mice were collected at E12, E14, E16, $\mathrm{E} 17, \mathrm{E} 18, \mathrm{P} 0, \mathrm{P} 5, \mathrm{P} 10$, and $\mathrm{P} 15$ and from adults aged $>8$ weeks.

Mice P5 or younger were anesthetized on ice. Mice older than P5 were anesthetized with pentobarbital, 25 $\mathrm{mg} / \mathrm{kg}$, and xylazine, $5 \mathrm{mg} / \mathrm{kg}$. Fixation was either with immersion $(E 14, E 16)$ or perfusion ( $>E 16)$ with $4 \%$ paraformaldehyde (PFA; 4\% PFA in $0.12 \mathrm{~m}$ phosphate buffer, $\mathrm{pH}$ 7.4). Dissected brains were postfixed for $2 \mathrm{~h}$ (embryonic ages) or overnight (all postnatal ages) before cryoprotection in $10 \%$ sucrose and freezing in isopentane cooled with dry ice at $-45^{\circ}$ to $-55^{\circ} \mathrm{C}$. In some in situ hybridization (ISH) protocols, no postfixation was performed. Frozen brains were then cut with a cryostat to either coronal or sagittal $20-\mu \mathrm{m}$-thick sections and collected as series of six. Frozen sections were stored at $-80^{\circ} \mathrm{C}$ before immunohistochemistry or ISH. Some brains were processed as floating sections and sectioned with a freezing microtome. In this case, the brains were cryoprotected in $30 \%$ sucrose and frozen directly on the platform of the cryotome at $-40^{\circ} \mathrm{C}$; serial $40-\mu \mathrm{m}$-thick coronal sections were collected in $1 \times$ PBS with $0.01 \%$ sodium azide. Sections were stored at $4^{\circ} \mathrm{C}$ before processing.

\section{ISH}

ISH was used to analyze EphA and ephrinA expression. Digoxigenin-labeled mRNA probes were transcribed from mouse EphA3, EphA4, EphA5, EphA7, Efna2, Efna3, and Efna5 cDNAs. Sense and antisense digest enzymes and polymerases of these probes are listed in Table 1. Sec-
Table 1. List of mRNA probes

\begin{tabular}{llllll}
\hline & \multicolumn{2}{c}{ Restriction enzyme } & & \multicolumn{2}{c}{ Polymerase } \\
\cline { 2 - 3 } \cline { 5 - 6 } Probe & Sense & Antisense & & Sense & Antisense \\
EphA3 & Hindlll & EcoRI & & T7 & T3 \\
EphA4 & Sacl/Sacll & Xhol/BamHI & & T7 & T3 \\
EphA5 & Xbal & BamHI & & T3 & T7 \\
EphA7 & BamHI & Xhol & & T7 & SP6 \\
Efna2 & Hindlll & EcoRV & & SP6 & T7 \\
Efna3 & Xhol & Bamhl & & T7 & SP6 \\
Efna5 & Hindlll & Xbal & & T3 & T7 \\
\hline
\end{tabular}

tions were air-dried for at least $2 \mathrm{~h}$ under a hood. Specific antisense RNA probes $(0.1-1 \mu \mathrm{g} / \mathrm{ml})$ were mixed with hybridization buffer $(50 \%$ formamide, $10 \%$ dextran sulfate, $1 \times$ Denhardt's, $5 \times$ SSC, and $250 \mu \mathrm{g} / \mathrm{ml}$ transfer RNA) and incubated at $52^{\circ} \mathrm{C}, 58^{\circ} \mathrm{C}$, or $65^{\circ} \mathrm{C}$ for $10 \mathrm{~min}$. Mixed hybridization buffer $(350 \mu \mathrm{l})$ was added to each section, covered with a coverslip, and incubated overnight at the same temperature. The sections were washed with PBS and PBS Triton $0.1 \%$ and incubated with antidigoxigenin (anti-Dig; $1 / 1000$ ) at $4^{\circ} \mathrm{C}$ overnight. Sections were washed with $1 \times$ PBS and NTMT (Tween 10\%; Tris$\mathrm{HCl}, \mathrm{pH}$ 9.5, $1 \mathrm{M} ; \mathrm{MgCl}_{2}, 1 \mathrm{M} ; \mathrm{NaCl}, 5 \mathrm{M} ; \mathrm{H}_{2} \mathrm{O}$ ) buffer and incubated at $37^{\circ} \mathrm{C}$ with NBT+BCIP or fast red (TR/naphthol AS-MX Tablets, Sigma-Aldrich, F4523-50 SET) to reveal the reaction. Duration of the revelation (2-24 h) was determined empirically according to the sensitivity of the probes and the concentration of the anti-Dig solution. The signal was checked with bright-field or fluorescence microscopy. Duration was kept identical for a given experiment (e.g., time course of expression). The sections were washed with $1 \times$ PBS and mounted in mowiol-Dabco (25 $\mathrm{mg} / \mathrm{ml}$ ) or processed with immunohistochemistry.

\section{Immunohistochemistry}

Immunohistochemistry was performed either on alternate series of sections or in combination with ISH. Sections were washed in PBS, then in PGT (PBS with $0.2 \%$ gelatin and $0.25 \%$ Triton $X-100$ ) four times for $15 \mathrm{~min}$. Sections were incubated overnight at $4^{\circ} \mathrm{C}$ with the following primary antibodies: anti-Tph2 (mouse monoclonal, 1/1000, Sigma-Aldrich), anti-5-HT (rabbit polyclonal, 1/1000, Sigma-Aldrich), anti-serotonin transporter (antiSERT; rabbit polyclonal, 1/1000, Calbiochem). For fluorescence microscopy, sections were then incubated for 2 $\mathrm{h}$ at room temperature with the following secondary antibodies: donkey anti-rabbit 488 (1/200, The Jackson Laboratory), donkey anti-rabbit Cy3 (1/200, The Jackson Laboratory), donkey anti-mouse $488(1 / 200$, The Jackson Laboratory), donkey anti-mouse Cy3 (1/200, The Jackson Laboratory), or phalloidin 594 (1/40, Invitrogen). Sections were rinsed in PB, mounted in mowiol-Dabco $(25 \mathrm{mg} / \mathrm{ml})$, and stored at $4^{\circ} \mathrm{C}$.

\section{$R T-q P C R$}

Brains of Pet1-Cre::RCE-GFP mice were collected at P5, P15, and adult (6 weeks). Brains were kept in $1 \times$ PBS on ice and sectioned in the coronal plane with a tissue chopper to $300-\mu \mathrm{m}$-thick sections. The DR was microdissected under 
Table 2. List of RT-qPCR primers

\begin{tabular}{lllll}
\hline Primer & mRNA Variant 1 & Product length & Forward primer & Reverse primer \\
EphA3 & NM_010140 & 116 & TGCGGGACTGTAACAGCATT & CGTGAACTGATGCTCTCGGA \\
EphA4 & NM_007936 & 90 & GAGGCTCCTGTGTCAACAACT & AGTTGCCAATGGGTACCAGC \\
EphA5 & NM_007937 & 98 & TTGGCTGTTGACCAGTTGGA & GTCCTCCAGGAAGGCTGTTG \\
EphA6 & NM_007938 & 90 & ACTGAAATCCGTGAGGTGGG & GACTGAGACCAGAGCGATGC \\
EphA7 & NM_010141 & 98 & TCCTCCTTAGTCGAGGTCCG & GCCACTCTCCTTCTGCACTG \\
EphA8 & NM_007939 & 95 & CATTGCTTTCCGCACGTTCT & TCCAGTAGGGTCGTTCACCA \\
\hline
\end{tabular}

a fluorescent microscope (Zeiss-MV10) and collected into 5 -ml tubes, which contained $2 \mathrm{ml}$ of cold $1 \times$ PBS; a cortical hemisphere was collected as a positive control. To obtain enough tissue for RNA isolation from the raphe, four cases were pooled together for each sample analyzed. Tissue was either directly processed for RNA isolation or fast frozen at $-80^{\circ} \mathrm{C}$. RNA isolation from tissue was done with Trizol reagent (Sigma-Aldrich). Samples were weighed $(\leq 50 \mathrm{mg})$ before homogenization, PBS was removed extensively, and $1 \mathrm{ml}$ of Trizol was added. Tissue was homogenized, and homogenates were transferred to 2-ml Eppendorf tubes with $0.2 \mathrm{ml}$ of chloroform, gently mixed for $15 \mathrm{~s}$, and centrifuged at $12000 \times \mathrm{g}$, for $15 \mathrm{~min}$ at $4^{\circ} \mathrm{C}$. The upper phase was collected, and RNA was precipitated with $0.5 \mathrm{ml}$ isopropyl alcohol, incubated at room temperature (5 min), and centrifuged at $12000 \times g$ for $10 \mathrm{~min}$ at $4^{\circ} \mathrm{C}$. After removal of the supernatant, the RNA pellet was air-dried and dissolved in $100 \mu \mathrm{l}$ Milli-Q water and stored at $-80^{\circ} \mathrm{C}$.

Possible DNA contamination was cleared using DNase I (Thermo), and RT-PCR was done with the SuperScriptll kit (Invitrogen). qPCR was performed with the Thermo SYBR Green Mix kit according to the manufacturer's instructions. Primers are listed in Table 2.

\section{Raphe culture and collapse assay}

E12 embryos were collected from Swiss timed-pregnant dams. Embryonic hindbrains were rapidly dissected as an open book in ice-cold $1 \times$ PBS. The rostral and caudal raphe were separated based on anatomical landmarks. The dissected raphe was further cut into $200-\mu \mathrm{m}$ explants with a tissue chopper. Explants were placed onto polylysine/laminin-coated glass coverslips (Marienfield, 0111540) in four-well culture boxes (Nunclon, 176740) in DMEM F-12 medium to which BSA (1\%), penicillin/streptomycin, glutamine $(200 \mathrm{~mm})$, and glucose $(50 \%)$ were added. Explants were cultured for $3-4 \mathrm{~d}$ at $37^{\circ} \mathrm{C}$, in $5 \%$ $\mathrm{CO}_{2}$. For the collapse assay, ephrinA5 (R\&D System, $374-E A)$ was added at different concentrations $(50,250$, $500 \mathrm{~mm}$ ) for $1 \mathrm{~h}$. Explants were then quickly washed in PBS, fixed in buffered $4 \%$ PFA for 30 min, and washed extensively before $5-\mathrm{HT}$ immunocytochemistry (anti-5-HT rabbit polyclonal, 1/1000, Sigma-Aldrich) and phalloidin 594 (1/40, Invitrogen) staining.

\section{Quantification of the collapse assay}

Explants were imaged with a fluorescence microscope. Only round-shaped explants that contained $5-\mathrm{HT}$ neurons were quantified. More than 100 growth cones from three

Table 3. Statistical analysis

\begin{tabular}{|c|c|c|c|}
\hline Line & Data structure & Type of test & Power \\
\hline b1, (Fig. 3D) & Homoscedastic & $\begin{array}{l}\text { One-way ANOVA } \\
\text { Tukey's multiple comparisons test }\end{array}$ & 0.8335 \\
\hline b2, (Fig. 3E) & Homoscedastic & $\begin{array}{l}\text { One-way ANOVA } \\
\text { Tukey's multiple comparisons test }\end{array}$ & 0.7097 \\
\hline c1, (Fig. 4C) & Homoscedastic & $\begin{array}{l}\text { One-way ANOVA } \\
\text { Tukey's multiple comparisons test }\end{array}$ & 0.9714 \\
\hline c3, (Fig. 4E) & Homoscedastic & $\begin{array}{l}\text { One-way ANOVA } \\
\text { Tukey's multiple comparisons test }\end{array}$ & 0.266 \\
\hline c4, (Fig. 4F) & Homoscedastic & $\begin{array}{l}\text { One-way ANOVA } \\
\text { Tukey's multiple comparisons test }\end{array}$ & 0.934 \\
\hline d1, (Fig. 5D) & Homoscedastic & Paired $t$ test (two tailed) & 1 \\
\hline d2, (Fig. 5E) & Homoscedastic & Paired $t$ test (two tailed) & 1 \\
\hline f2, (Fig. 7E) & Homoscedastic & Unpaired t test (two tailed) & 1 \\
\hline g1, Fig. 7l & Homoscedastic & Unpaired $t$ test (two tailed) & 1 \\
\hline g2, Fig. $7 \mathrm{~J}$ & Homoscedastic & Unpaired $t$ test (two tailed) & 1 \\
\hline
\end{tabular}

Statistical calculations were done with GraphPad Prism 6. Powers of each experiment were calculated by an online power calculator: https://www.anzmtg.org/stats/PowerCalculator. 
A

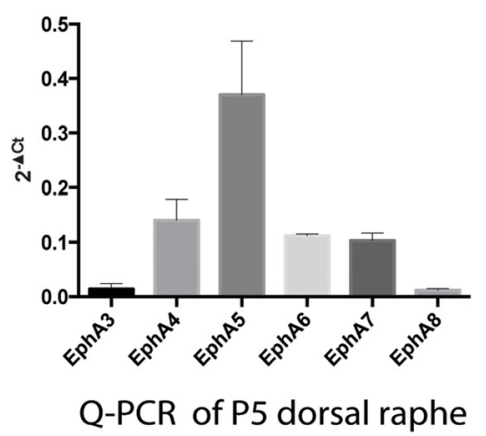

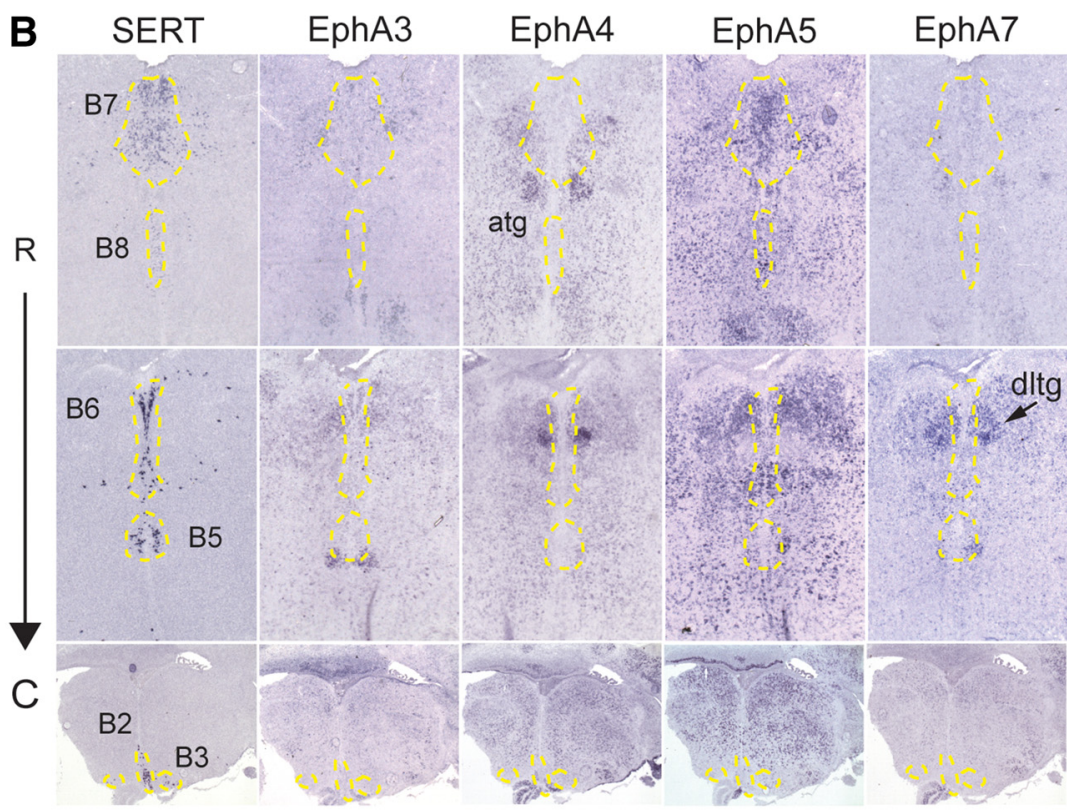

In situ hybridization -raphe P5

Fig. 1. EphA receptor gene expression in the developing mouse raphe. A, qPCR of EphA3, EphA4, EphA5, EphA6, EphA7, and EphA8 mRNAs in DR extracts from P5 mice $\left(n=4\right.$ mice/experiment). Relative mRNA expression was calculated as $2^{-\Delta C t}$ (delta of cycle threshold). Data are presented as mean \pm SEM from three independent experiments. $\boldsymbol{B}$, In situ hybridization of SERT, EphA3, EphA4, EphA5, and EphA7 mRNAs is shown at three different rostro-caudal levels of the raphe nuclei, including DR (B7), caudal DR (B6), rostral MnR (B8), caudal MnR (B5), raphe pallidus (B1), obscurus (B2), and magnus (B3). Coronal serial sections (20 $\mu \mathrm{m}$ thick) were labeled with the five different probes. Localization of 5-HT neurons as revealed by SERT expression was outlined with dashed yellow lines that were transferred to the consecutive sections on the series. This shows that only EphA5 labeling coincides clearly with the contours of B7 and B8. EphA4 and EphA7 are also strongly expressed in the brainstem, but signal is mainly detected in cell groups such as the anterior tegmental nucleus (atg), the dorsal tegmental nucleus (dtg), or the inferior olive (io) that come very close to the raphe. Scale bar $=250 \mu \mathrm{m}$.

explants for each condition were counted using a $63 \times / 1.25$ objective. The number of collapsed/noncollapsed growth cones was counted for both 5-HT and non-5-HT axons, comparing 5-HT immunostaining with phalloidin staining. Results from three independent experiments were used to calculate the mean ratio \pm SEM per condition.

\section{Anterograde tracing}

We used an adeno-associated virus (AAV1.CAG.TdTomato. WPRE.SV40 ref: AV-1-PV3365, Penn Vector Core) to express TdTomato fluorescence in the DR neurons and projections. A single injection ( $20 \mathrm{nl}$ of the virus undiluted) was done in the DR using glass-pulled capillaries (5-0001001-X10, Drummond; puller model 720 , Kopf, heat of 14.5 and solenoid 2). DR stereotaxic injections were performed as previously described (Muzerelle et al., 2016). Adult ephrinA5 KO mice and control littermate $(+/+$ or $+/-)$ mice were anesthetized with ketamine $(150 \mathrm{mg} / \mathrm{kg}) /$ xylazine $(10 \mathrm{mg} / \mathrm{kg})$. Animals were positioned on a foam board horizontally, the head was fixed and kept horizontal, and bregma coordinates were measured to calculate the position of the injection site and the angle of stereotaxic arm. To target the DR, the following coordinates were used: antero-posterior, $0.5 \mathrm{~mm}$ to lambda; mediolateral, $1 \mathrm{~mm}$; dorsoventral, $-3.2 \mathrm{~mm}$. The animals were kept for 3 weeks and were perfused by 4\% PFA. Brains were processed as described above, collecting serial $50-\mu \mathrm{m}$ coronal sections throughout the brain.
In utero electroporation of EphrinA construct

GFP-Efna3 was subcloned into the vector pCIGTdTomato. The pCIG-TdTomato vector without the insert was used for the control condition. Both plasmids were purified by Qiagen EndoFree Plasmid Maxi kit, and stored at a final concentration of $2.5 \mu \mathrm{g} / \mu \mathrm{l}$.

To target gene expression in the amygdala, we followed a previously described in utero electroporation protocol (Remedios et al., 2004; Huang et al., 2014). The plasmids $(1 \mu \mathrm{g} / \mu \mathrm{l})$ were mixed with $1 \%$ Fast Green (F7252, SigmaAldrich) and injected into one of the lateral ventricles of E12.5 embryos with glass-pulled micropipettes. A 3-mmdiameter electrode (LF650P3, Bex Co.) was placed toward the caudal and ventral part of the telencephalon. Six electric pulses (30 V, 50-ms pulse length) with 950-ms intervals were applied using an electroporator (CUY21, Bex Co.). After delivery, foster mothers delivering at the same time as the experimental subjects adopted the newborn pups. The electroporated pups were perfused at P5 and processed for immunocytochemistry as described above.

\section{Image acquisition}

For bright-field microscopy, histological sections were imaged using a slide scanner (Nanozoomer 2.0-HT C9600, Hamamatsu) $20 \times$ objective or captured with a CoolSnap camera mounted on a bright-field microscope (Provis, Olympus). For illustration purposes, images from the 
A

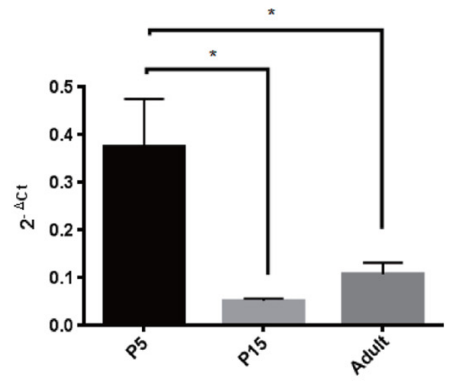

Q-PCR of EphA5 in DR
B

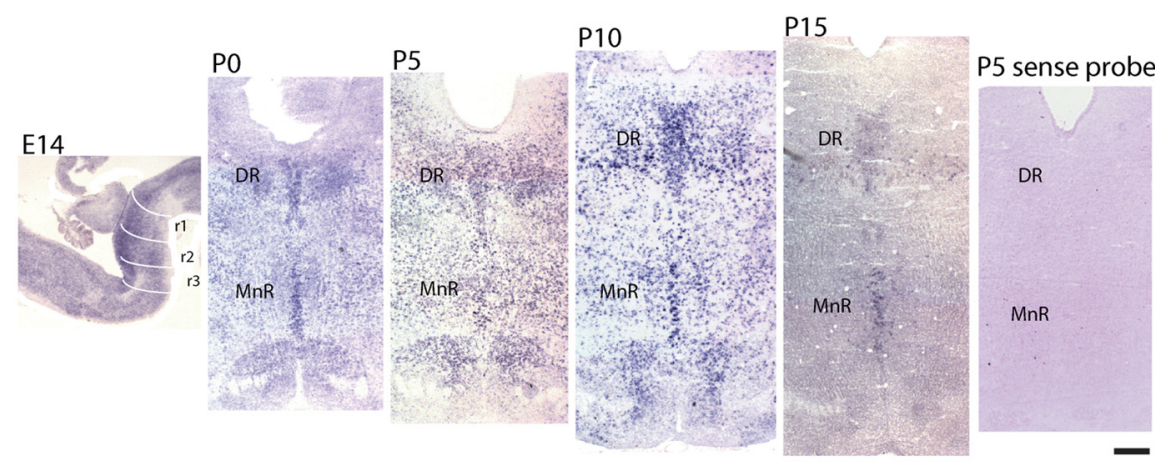

The expression of EphA5 in developing raphe
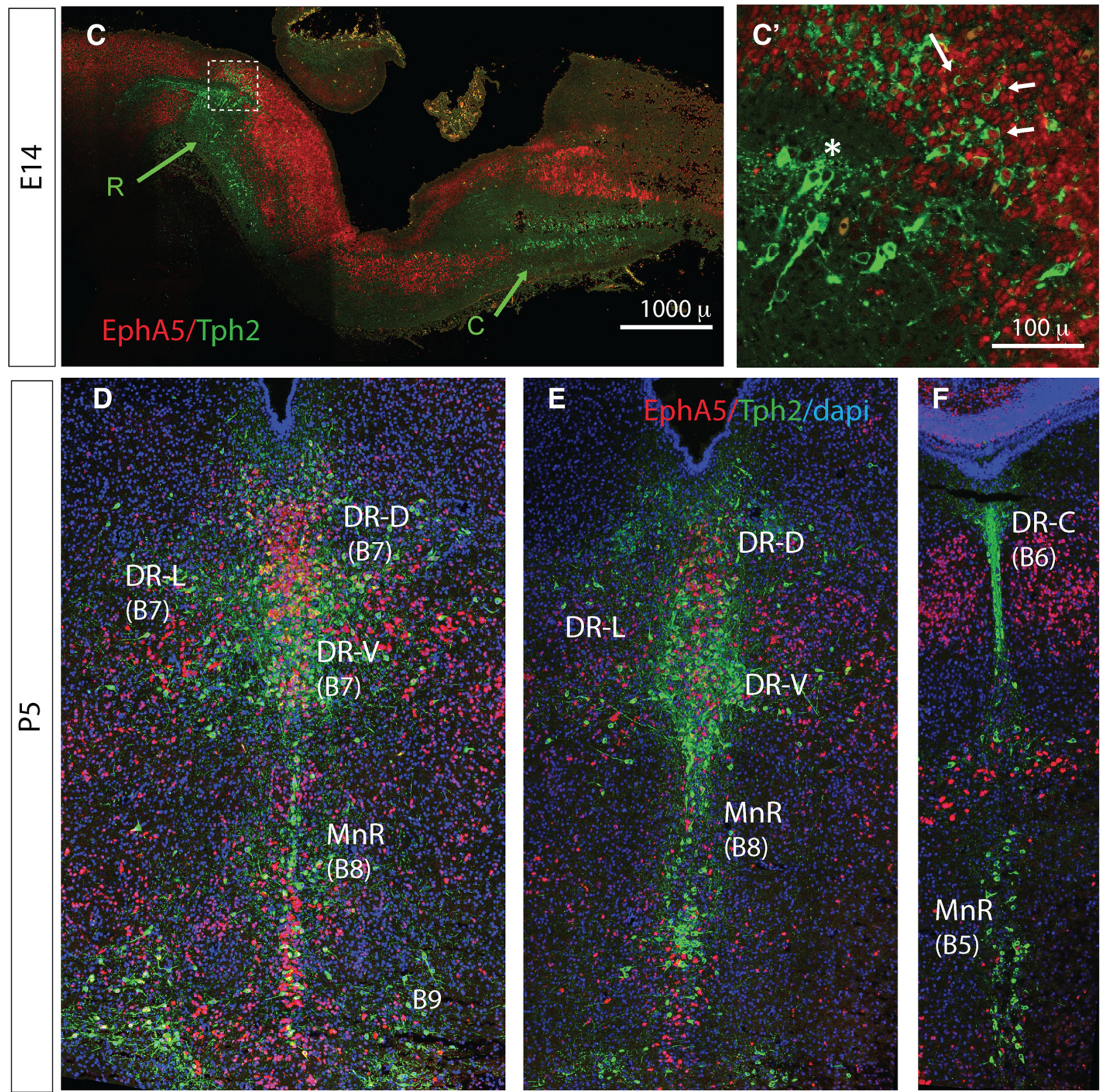

Fig. 2. EphA5 is expressed in serotonergic neurons during embryonic and postnatal development. $\boldsymbol{A}$, qPCR of EphA5 mRNAs in DR extracts from P5 $(n=3)$, P15 $(n=3)$, and adult $(n=3)$. Relative mRNA expression was calculated as $2^{-\Delta C t}$. Data are presented as 


\section{continued}

mean \pm SEM from three independent experiments, $\boldsymbol{B}$, Time course of EphA5 expression in the developing raphe was analyzed on sagittal (E14) and coronal (P0, P5, P10, P15) sections through the raphe nuclei. Note the decrease in EphA5 expression by P15. No expression is detected using the sense probe of EphA5. Scale bar $=500 \mu \mathrm{m}$. $\boldsymbol{C}$, Colocalization was visualized on confocal images after Tph2-immunostaining (green) and EphA5 ISH (red). Sagittal section of E14 mouse brain through the rostral (R) and caudal (C) raphe clusters that are indicated with arrows. Note that the dorsal part of the rostral cluster overlaps with EphA5 labeling, whereas the ventral part does not. $\boldsymbol{C}^{\prime}$, High-power image of the boxed area in $\boldsymbol{A}$. Arrows indicate colocalized neurons (red nuclear labeling for EphA5 and green cytoplasmic labeling for Tph2); the asterisk shows Tph2 ${ }^{+}$neurons with no EphA5 expression. Scale bar $=1 \mathrm{~mm}$ $(\boldsymbol{A}), 100 \mu \mathrm{m}\left(\boldsymbol{A}^{\prime}\right)$. D, E, F, Coronal sections of a P5 mouse hindbrain at rostral $(\boldsymbol{B})$, intermediate $(\boldsymbol{C})$ and caudal $(\boldsymbol{C})$ levels of the raphe. Sections were counterstained with DAPI. Scale bar $=500 \mu \mathrm{m}$

nanozoomer were exported in Tiff format using the NDP View2 software (Hamamatsu).

For fluorescence microscopy, images were acquired with a Leica DM 6000B system using a $40 \times / 0.70$ oil objective (tissue cultures) or a Leica SP5 confocal system (colocalization and fiber density analyses) equipped with an Argon laser (for the 488-nm excitation), a diode $561 \mathrm{~nm}$ and $\mathrm{HeNe} 633 \mathrm{~nm}$. Z-stacks of confocal images were acquired at $1024 \times 1024$-pixel resolution, with a pinhole set to one Airy unit and optimal settings for gain and offset.

\section{Image analyses}

EphA5-Tph2 colocalization was analyzed on P5 brains processed from three independent experiments. Cryostat sections through the brainstem (20 $\mu \mathrm{m}$ thick) were collected as series of six. One series was processed for combined EphA5 HIS (Fast Red Chromogen), Tph2 immunohistochemistry (revealed with Alexa 488), and DAPI and imaged with a confocal microscope. These three fluorochromes were sequentially acquired with a $40 \times /$ 1.25-NA Plan-Apochromat objective at three different rostrocaudal levels through the raphe (Paxinos Atlas, levels: bregma $-4.3,-4.6$, and $-4.9 \mathrm{~mm}$ ). The whole hindbrain area containing Tph2 ${ }^{+}$neurons was acquired including the different subdivisions of the DR in the dorsal part (DRD), the ventral part (DRV), the lateral wings (DR-LW), and the caudal part (DR-C, B6). Acquisitions included the $\mathrm{MnR}$, which comprises the B8 and B5 cell groups, and the supralemniscal B9 cell groups. Confocal stacks were analyzed with ImageJ. A $150 \times 150-\mu \mathrm{m}$ square mask was used for random selection of counting areas. Three random selections were positioned on each distinct 5-HT subnucleus. A cell counter plugin was used to count the $\mathrm{Tph}^{+}$cells on individual confocal sections, $\mathrm{EphA} 5^{+}$cells, and colocalized neurons. It should be noted that in contrast to BCIP, the Fast Red used as a chromogen for ISH mRNA revelation generally diffuses into the nucleus of labeled cells, in contrast to the Tph2 labeling that remains in the cytoplasm (e.g., Fig. 2 C, Fig. 3).

Fiber density was analyzed in two different ways, anterograde tracer injections and in utero electroporation. In the olfactory bulb and amygdala, confocal images were acquired at $4-\mu \mathrm{m}$ intervals over $20 \mu \mathrm{m}$ in $z$. A maximum $z$-projection of the image stacks was performed with ImageJ. Then, a circular mask of $20-\mu \mathrm{m}$ diameter was used for random sample selection. All labeled fibers that crossed the edge of the mask were counted with a cell counter to compute linear densities. In the hypothalamus, where there is a high density of $5-\mathrm{HT}$ innervation, single confocal images were analyzed. Confocal 16-bit images were copied to ImageJ with an 8-bit format and processed as described (Kiyasova et al. 2011). Subtraction of the background was done with a 20-pixel rollerball, and a binary image was obtained after applying a fixed-range threshold for all the images. The nuclear region of interest (ROI) was delimited, and the area occupied by the labeled fibers was measured within a circular mask $(100-\mu \mathrm{m}$ diameter). The mask was randomly placed in three to five different locations over the structure, to calculate a mean density value per area and per animal.

\section{Statistical analyses}

All the statistical analyses applied were performed with GraphPad Prism 6. One-way ANOVA was performed for the GPCR, colocalization, and collapse assays. To evaluate differences between any of two samples, Tukey's multiple comparisons was performed. Student's $t$-test was performed for intergroup comparisons in the fiber density analyses. Unpaired $t$-test was used for comparison of independent samples, and paired $t$-test was done for analyses comparing ipsilateral and contralateral innervation in the same case. Data are expressed as mean \pm SEM; $p<0.05$ was considered significant. Statistical tests are shown in Table 3.

\section{Results}

\section{Expression of EphA receptors in the raphe nuclei}

In rodents, 5-HT neurons of the hindbrain start extending axons by E12, reach most of their forebrain targets between $\mathrm{E} 15$ and $\mathrm{P} 1$, and start arborizing in these targets over the following postnatal days (Lidov and Molliver, 1982, in rats; Kiyasova and Gaspar, 2011, in mice).

We began by screening the expression of EphA receptors at P5, when the 5-HT axons are still actively growing and branching in their targets (Lidov and Molliver, 1982) and where the DR and the MnR can be clearly individualized. qPCR analyses were performed on microdissected DR from Pet1-GFP mice (Scott et al., 2005). EphA3, A4, $A 5, A 6, A 7$, and $A 8$ mRNAs were analyzed, using GAPDH as a housekeeping gene. This analysis showed that EphA5 is the most abundant EphA receptor in the DR at P5, with lower expression of EphA4, EphA6, and EphA7 and no detectable expression of EphA3 and EphA8 (Fig. $1 A)$. To determine the cellular localization of the Eph genes, ISH was performed on consecutive serial coronal sections through the raphe, using specific mRNA probes to EphAs (Table 1) and SERT used as a marker of the 5-HT raphe neurons. This showed that among the Eph genes 

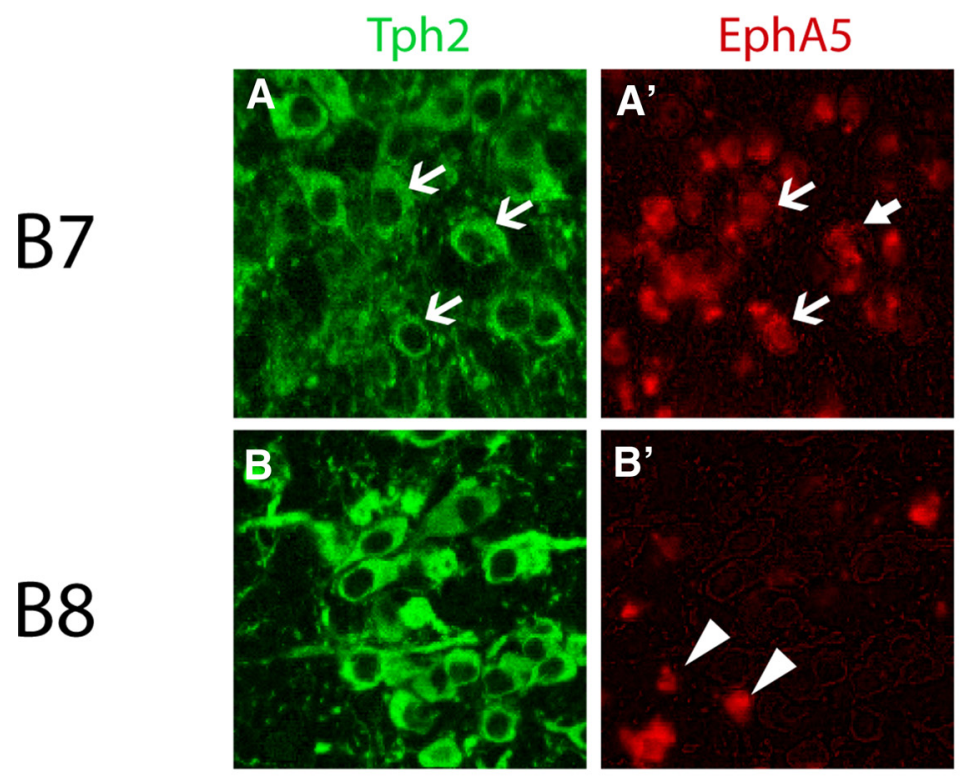

Tph2/EphA5/DAPI


\section{$\%$ Tph2+ neurons expressing EphA5 \\ All raphe nuclei \\ in the DR}

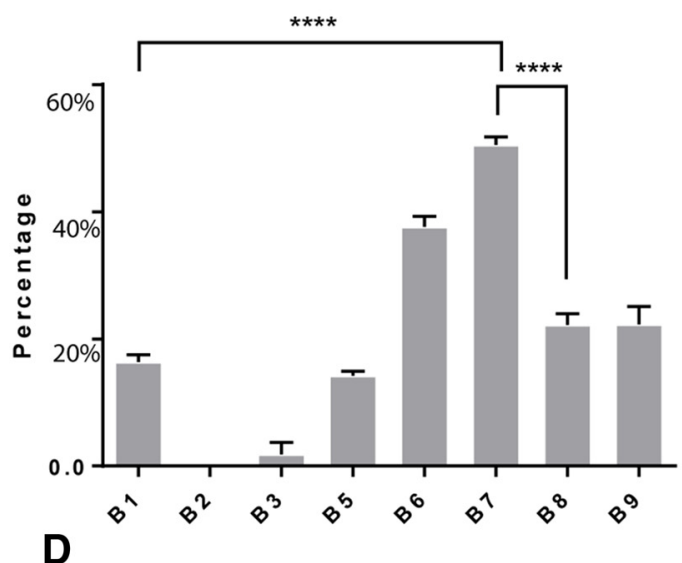

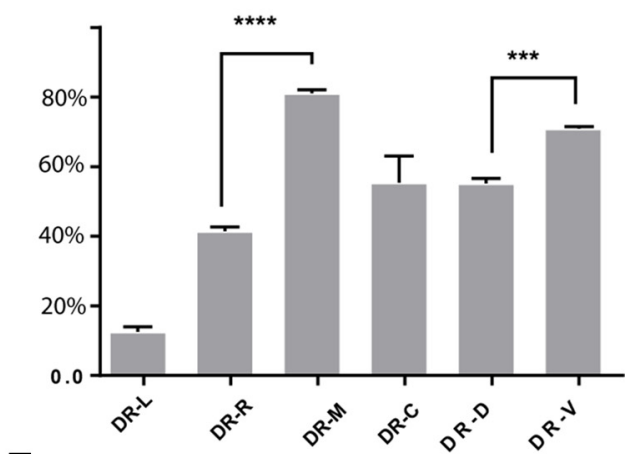

E

Fig. 3. Quantification of EphA5-Tph2 colocalization in distinct raphe nucleus. $\boldsymbol{A}-\boldsymbol{C}$, High-power confocal images in B7, B8, and B2, showing the difference in colocalization of EphA5 and Tph2 in different raphe nuclei. White arrows point to Tph2+EphA5 colocalized neurons; arrowheads show neuron containing only EphA5. Scale bar $=50 \mu \mathrm{m} . \boldsymbol{D}, \boldsymbol{E}$, Histograms summarizing the percentage colocalization among the different raphe nuclei, subdivided as the B1-B9 cell groups $(\boldsymbol{D})$ and within the DR, where colocalization was compared at three rostro-caudal levels, caudal DR DR-C), middle DR (DR-M), rostral DR (DR-R), and three DR subdivisions, DR lateral (DR-L), DR dorsal (DR-D), and DR ventral (DR-V). Data are presented as mean \pm SEM $(n=3)$. One-way ANOVA, $* * * p<0.005$ and $* * * * p<0.001$.

examined, only EphA5 was clearly localized in the DR and the MnR containing 5-HT neurons, but with no visible expression in the raphe magnus, obscurus, and pallidus (the B1-B3 raphe cell groups; Fig. 1B). The other EphA genes, EphA4 and EphA7, were not detectable in any of the raphe nuclei but were localized to nuclei, such as the 
Table 4. Counts of Tph2-immunopositive and EphA5-expressing neurons and colocalized neurons in different raphe nuclei

\begin{tabular}{|c|c|c|c|c|c|c|c|c|}
\hline Neuron & B1 & B2 & B3 & B5 & B6 & B7 & B8 & B9 \\
\hline Tph2 $^{+}$ & $8.2 \pm 0.9$ & $2.8 \pm 0.1$ & $7.4 \pm 0.9$ & $5.1 \pm 0.1$ & $30.7 \pm 1.9$ & $11.2 \pm 0.9$ & $5 \pm 0.4$ & $7.3 \pm 0.5$ \\
\hline EphA5 ${ }^{+}$ & $19.3 \pm 3.3$ & $3.3 \pm 1.7$ & $2.9 \pm 1.5$ & $8.9 \pm 0.2$ & $41.2 \pm 2.9$ & $23.3 \pm 2.2$ & $18.9 \pm 1.6$ & $16.9 \pm 0.8$ \\
\hline $\mathrm{Tph}^{+} / \mathrm{EphA}^{+}$ & $1.3 \pm 0.2$ & 0 & $0.1 \pm 0.1$ & $0.7 \pm 0.1$ & $11.5 \pm 0.6$ & $5.7 \pm 0.4$ & $1.1 \pm 0.1$ & $1.6 \pm 0.2$ \\
\hline Tph2 colocalized, \% & $16.4 \pm 1$ & 0 & $1.8 \pm 1.9$ & $14.3 \pm 0.7$ & $37.6 \pm 1.6$ & $50.5 \pm 1.2$ & $22.3 \pm 0.2$ & $22.3 \pm 2$ \\
\hline
\end{tabular}

Data are mean cell numbers \pm SEM/area obtained from counts done in three cases in ROI covering the different raphe nuclei (B1-B9) . All cells (validated by DAPI staining) immunolabeled for Tph2, for EphA5 and double-labeled for Tph2 and EhpA5 were counted in three different ROIs (dimension 0.225 mm ${ }^{2}$ ) for each structure and for each case and checked for colocalization. Percentage of the colabeled Tph2 neurons is indicated.

dorsal lateral tegmental nuclei and superior olive, that abut the raphe nuclei (Fig. 1B), which likely explains their detection when analyzed by qPCR on dissected DR tissue. Sense probes were used as controls.

Overall, these results indicate a preferential expression of EPhA5 over other EphA receptors in the developing DR and $\mathrm{MnR}$.

\section{EphA5 expression is dynamically regulated during raphe development}

To evaluate the possible developmental impact of EphA5 at different stages of raphe development, we analyzed its expression timeline. Serial sagittal $(\mathrm{E} 14, n=4)$ and coronal (postnatal and adult) sections were processed for EphA5 ISH PO $(n>5)$, P5 $(n>5)$, P10 $(n>5)$, P15 $(n>5)$, and adult $(n=2)$. EphA5 expression was detectable in the rostral raphe at E14 (Fig. 2B). This expression was maintained at a high level over the first week after birth and subsequently declined by P15 (Fig. $2 B$ ) up to adulthood, where only weak expression was detectable (not shown). To obtain a quantitative evaluation of the time course of expression, qPCR measures of EphA5 mRNA were done on DR tissue from P5, P15, and adult brains (Fig. 2A). This showed a significant decrease of EphA5 expression between P5 and P15 ( $p<0.05)$, consistent with the ISH observation.

These results indicated that EphA5 is dynamically regulated during development, with highest expression in early postnatal life and a subsequent decline in expression by P15.

\section{Serotonergic raphe nuclei differ in EphA5 expression pattern}

Hindbrain raphe nuclei contain a heterogeneous neuronal population that includes, in addition to 5-HT neurons, glutamatergic, GABAergic, and peptide-containing neurons. To determine whether EphA5 is specifically expressed in the serotonergic neurons, we combined fluorescent EphA5 ISH and tryptophan hydroxylase (Tph2) immunocytochemistry (Nguyen et al. 2001; Fig. 2). At E14, 5-HT neurons have not yet achieved their full migration, making it difficult to clearly distinguish all the individual raphe cell groups other than the two main rostral and caudal clusters. However, a distinction could be made between the dorsal and ventral Tph $2^{+}$neurons of the rostral cluster that corresponds to the prospective $\mathrm{DR}$ and $\mathrm{MnR}$, respectively (Fig. 2C). In the dorsal part, a large number of colocalized EphA5-Tph2 ${ }^{+}$neurons were found (Fig. $2 C^{\prime}$ ), whereas rare colocalization was found in the ventral part. In contrast, in the medulla, the caudal $\mathrm{Tph}^{+}$cluster appeared to be entirely segregated from the EphA5-expressing region.

A more detailed quantitative evaluation of EphA5-Tph2 colocalization was done at P5, since distinction of these components can be done clearly at this stages (Fig. 2D, $E)$, and this postnatal developmental stage is highly relevant to the ingrowth of 5-HT axons in their targets. Colocalization of Tph2 and was evaluated quantitatively in the different subnuclei (Fig. 3; Tables 4 and 5). The highest colocalization index was found in the DR (B7, all subcomponents pooled), where more than half of the $5-\mathrm{HT}$ neurons expressed EphA5 $(50.2 \% \pm 2.2 \%, n=3$, Fig. $3 A, D)$, whereas the lowest colocalization ratio was noted in the caudal (B1-B3) raphe cell groups (Fig. 3C, D). In the MnR (B5, B8), a strong expression of EphA5 was visible, but only a minority (14\% and $22 \%$, respectively) of the $5-\mathrm{HT}$ neurons expressed EphA5 (Fig. 3B, D). Further heterogeneous expression was observed within the DR, where colocalization was compared at three different rostrocaudal levels (Fig. 3E) and in three different DR subdivisions (lateral, dorsal, ventral; Fig. $3 E$ and Table 5); Medially located DR neurons have a higher percentage of colocalized neurons than the laterally located DR neurons (Fig. 2B, C; Fig. 3E). Overall, this colocalization pattern indicates a clear topography of EphA5 expression in the raphe subgroups, with a rostral to caudal decreasing expression that was visible during embryonic stages (Fig. 2C) and maintained at P5 (Fig. 3). Such differences in expression of EhpA5 between the different 5-HT cell groups suggested that EphA5 signaling could be involved in the differential targeting of these various 5-HT neurons.

Table 5. Counts of Tph2-immunopositive and EphA5-expressing neurons and colocalized neurons in the dorsal raphe (B7; mean \pm SEM, $n=3$ )

\begin{tabular}{|c|c|c|c|c|c|c|}
\hline Neuron & DR-LW & DR-C & DR-M & DR-R & DR-D & DR-V \\
\hline Tph2 $^{+}$ & $4.5 \pm 0.6$ & $17.8 \pm 2.3$ & $20.2 \pm 1.6$ & $21 \pm 2$ & $20.1 \pm 2.1$ & $17.9 \pm 1.8$ \\
\hline EphA5 ${ }^{+}$ & $20 \pm 1.2$ & $20.6 \pm 3.6$ & $38.3 \pm 4.3$ & $18.6 \pm 3.1$ & $32.8 \pm 3.5$ & $26.2 \pm 4.5$ \\
\hline $\mathrm{Tph}^{+} / \mathrm{EphA}^{+}$ & $0.6 \pm 0.1$ & $7.4 \pm 1.1$ & $16.4 \pm 1.4$ & $11.3 \pm 0.7$ & $11.1 \pm 1.4$ & $12.7 \pm 1.2$ \\
\hline Tph2 colocalized, \% & $12.6 \% \pm 1.5$ & $41.5 \pm 1.2$ & $81.1 \pm 1$ & $44.4 \pm 7.7$ & $55.2 \pm 1.4$ & $70.9 \pm 0.6$ \\
\hline
\end{tabular}




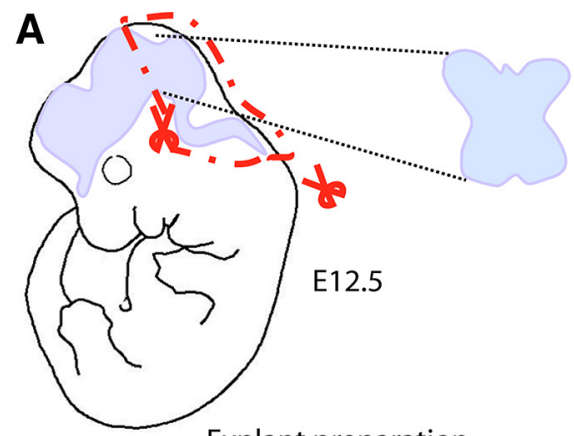

Explant preparation
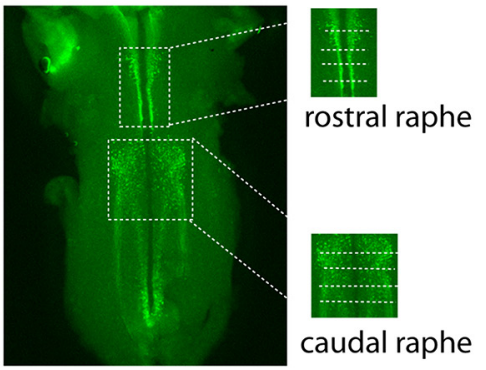
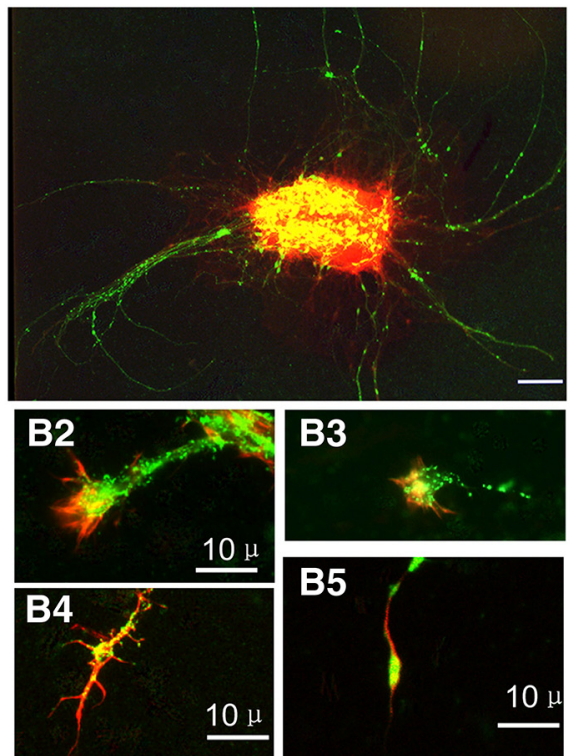

B3

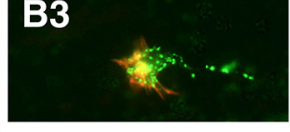

B5

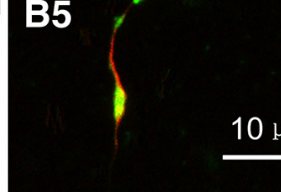

rostral raphe

caudal raphe

$\%$ collapse response of $5-\mathrm{HT}$ axons

C

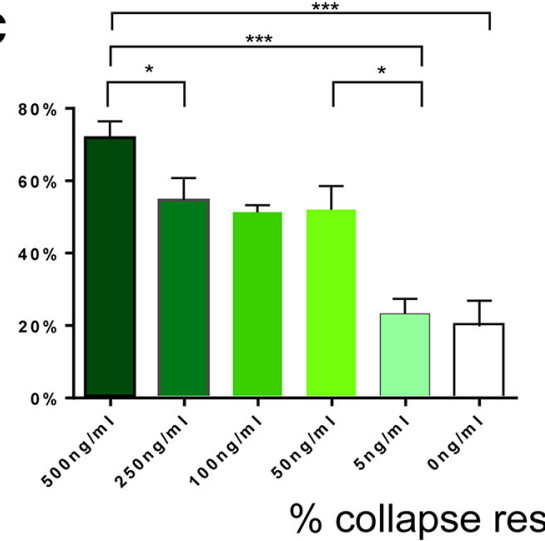

E



D

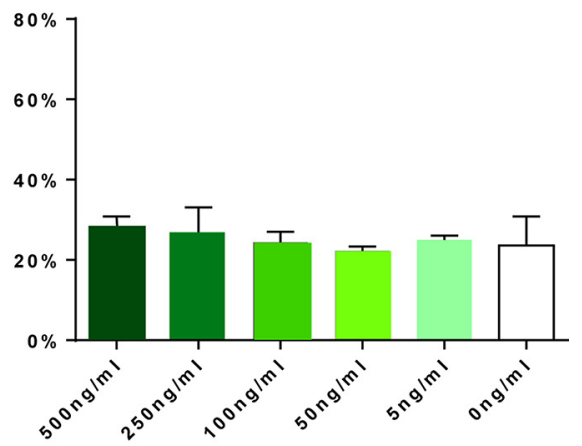

$\mathbf{F}$

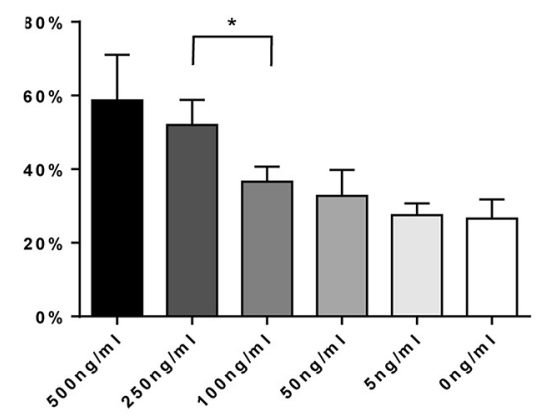

Fig. 4. EphrinA5 induces collapse of rostral raphe serotonin axons in vitro. $\boldsymbol{A}$, Explant preparation: hindbrain was dissected as an open book from E12 embryos; the rostral and caudal raphe were dissected as depicted on a whole-mount E12 hindbrain stained for 5-HT. Scale bar $=2 \mathrm{~mm}$. B , Raphe explants (3DIV) were stained for 5-HT (green) and phalloidin (red). B1, 5-HT ${ }^{+}$axons emerging from the explant. B2-B5, 5-HT-labeled growth cones displaying either a normal fan-like morphology (B2, B3) or collapsed growth cone with branch-like morphology (B4) or a long trailing process and an actin-rich retraction bulb. Scale bar = $100 \mu \mathrm{m}$ (B1), $10 \mu \mathrm{m}$ (B2-B5). C-F, Histograms show the percentage of collapsed growth cones when explants are exposed to different concentrations of ephrinA5. $\boldsymbol{C}, \boldsymbol{D}, 5-\mathrm{HT}-\mathrm{labeled}$ axons from rostral $(\boldsymbol{C})$ and caudal $(\boldsymbol{D})$ explants; $\boldsymbol{E}, \boldsymbol{F}$, non-5-HT axons from rostral $(\boldsymbol{E})$ and caudal $(\boldsymbol{F})$ explants $(>5$ explants and $>100$ growth cones per condition). Data are presented as mean \pm SEM. One-way ANOVA, $* p<0.05, * * p<0.01, * * * p<0.005$, and $* * * * p<0.001$. 



Fig. 5. Overexpression of ephrinA3 downregulates serotonergic innervation in the amygdala and piriform cortex. $\boldsymbol{A}-\boldsymbol{B}^{\prime \prime}$, Electroporated neurons were revealed by TdTomato with the ephrinA3 plasmid in the targets of Am $(\boldsymbol{A})$ and Pir (B). Corresponding 5-HT immunocytochemistry from the electroporated $\left(\boldsymbol{A}^{\prime}, \boldsymbol{B}^{\prime}\right)$ and nonelectroporated $\left(\boldsymbol{A}^{\prime \prime}, \boldsymbol{B}^{\prime \prime}\right)$ sides. Note the decrease of 5-HT fibers in the outlined area compared with control side. Scale bar $=100 \mu \mathrm{m}$. $\boldsymbol{C}$, Target of electroporation (TdTomato) on a coronal section of P5 mouse brain at the level of amygdala. Arrows show electroporated Am and Pir. Scale bar $=1000 \mu \mathrm{m}$. $\boldsymbol{D}, \boldsymbol{E}$, Scattergram shows serotonergic fiber density in the electroporated (red) versus nonelectroporated (blue) amygdala $(\boldsymbol{D})$ and piriform cortex (E). Overexpression of ephrinA3 resulted in a significant decrease of 5-HT fiber density compared with control groups $(n=5)$. Data are presented as mean \pm SEM. Paired $t$ test was used for ipsilateral vs. contralateral, $* * * p<0.005$. 


\section{Collapse response of 5-HT raphe neurons after the ephrinA application}

To examine the functional role of EphA5 expression on 5-HT axon outgrowth, we took advantage of the clear-cut differential expression of EphA5 between the rostral (B5B9) and caudal-medullary (B1-B3) clusters of 5-HT neurons at embryonic ages and compared their response to application of the ligand ephrinA5. Raphe explants from E12 hindbrains were dissected as illustrated (Fig. 4A) and cultured for $48 \mathrm{~h}$ on glass coverslips. In explants from the rostral raphe, ephrinA5-FC induced the collapse of a large fraction of $5-\mathrm{HT}$ growth cones (Fig. 4B). A dosedependent effect was noted: $71.3 \% \pm 4.5 \%$ of the $5-\mathrm{HT}$ growth cones were collapsed at the highest concentration tested $(500 \mathrm{ng} / \mathrm{ml})$ and $45-50 \%$ at intermediate concentrations (50-250 ng/ml; Fig. $4 C$ ). In caudal raphe explants, ephrinA5 application did not induce a significant collapse response compared to controls at any of the concentrations tested (Fig. 4B2, D).

Because EphA5 is also expressed in a large number of non-5-HT neurons in both the rostral and caudal raphe areas (Table 4), we also measured the collapse responses of the non-5-HT axons. The non-5-HT growth cones showed a significant dose-dependent collapse response in both rostral and caudal explants (Fig. 4E, F), thus not displaying the regional selectivity noted for $5-\mathrm{HT}$ growth cones.

Overall, these experiments demonstrated that the pattern of EphA5 expression in 5-HT raphe neurons correlated with a repulsive response to the application of ephrinA5-FC. Interestingly, there was a dose-response effect, suggesting that differences in the ligand/receptor ratio could contribute to a differential targeting of $5-\mathrm{HT}$ raphe neurons.

\section{5-HT innervation is reduced by ectopic ephrinA expression in the amygdala}

Next, we investigated the effects of ephrinA ligands for in vivo $5-\mathrm{HT}$ axon targeting using an overexpression strategy. We focused on the amygdala and piriform cortex, which are preferential targets of the DR 5-HT neurons (Muzerelle et al. 2016) and express only very low levels of the main EphA5 ligands, ephrinA2, ephrinA3, and ephrinA5, based on our own observations, confirming previously published reports (Deschamps et al., 2010; Gerstmann et al. 2015) and available public resources (Allen Brain Atlas, http://developingmouse.brain-map.org/ gene/show/13415, 13416, 13418). This suggested that the amygdala and piriform cortex could be permissive for the ingrowth of DR axons that express high levels of EphA5 receptors. To examine this possibility, we used an in utero electroporation strategy to ectopically express ephrinA3 that has been shown to have the highest affinity for EphA5 (Gale et al., 1996). An ephrinA3 cDNA fragment was subcloned into a pCIG-TdTomato vector; the plasmid with or without the ephrinA3 insert was electroporated into the amygdala and piriform cortex at E12.5, and the brains were processed at P5 for 5-HT immunocytochemistry. No structural changes were observed on the electroporated/nonelectroporated side, as evaluated by Nissl staining. The electroporated cells were visible in different parts of the amygdala (basolateral and basomedial amygdaloid nucleus) and in the piriform cortex (Fig. 5A-C). Measures of 5-HT fiber density showed a significant decrease of 5-HT fibers on the electroporated amygdala $(0.07 \pm 0.01 \mathrm{fibers} / \mu \mathrm{m})$ and piriform cortex $(0.07 \pm 0.01$ fibers $/ \mu \mathrm{m})$ compared with the contralateral nonelectroporated amygdala $(0.21 \pm 0.03$ fibers $/ \mu \mathrm{m})$ and piriform cortex (Figs. 5D, 7E ). Conversely, in the cases electroporated with the control vector, the density of $5-\mathrm{HT}$ fibers was unchanged compared to the nonelectroporated side. This result indicated that ectopic expression of ephrinA3 during development can specifically reduce $5-\mathrm{HT}$ rapheamygdala innervation $(n=5, p<0.005)$.

\section{EphrinA5 is required for the differential forebrain targeting of B7/B8 raphe neurons}

To investigate the role of endogenous ephrins in 5-HT axon targeting, we investigated the effects of loss of function of one of the major EphA5 ligands, ephrinA5, using the ephrinA5 $\mathrm{KO}$ mouse model. We reasoned that 5-HT neurons with high EphA5 expression in the raphe should avoid innervating brain regions containing high levels of the ligand ephrinA5. ISH of an Efna5 riboprobe was done on serial sections of P5 brains. We focused on three main regions with high ephrinA5 expression, the olfactory bulb (OB; Fig $6 C$ ), the ventromedial hypothalamus (VMH), and the suprachiasmatic nucleus (SCN; Fig. $7 A, F)$. Indeed, previous selective anterograde tracing from these DR and MnR had shown that the DR targets the granule cell layer of the OB seems arrested by the mitral cell layer, whereas the MnR targets the glomerular layer (GL) of the OB (Fig. 6C; Steinfeld et al. 2015; Muzerelle et al., 2016). Similarly, 5-HT DR axons consistently avoid the $\mathrm{VMH}$ and SCN that are instead innervated by $\mathrm{MnR}$ raphe neurons (Bang et al. 2012; Muzerelle et al. 2016)

Anterograde tracing of the DR neurons was done with an AAV viral vector expressing TdTomato comparing ephrinA5 $\mathrm{KO}$ and wild-type (WT) mice. We evaluated the extent of anterogradely labeled neurons that were 5-HTimmunopositive in the raphe (Fig. $6 A$ ) and the size of the injection site (Fig. 6B). Transfection was limited to the DR (Fig. 6B), and the number of transfected 5-HT cells was equivalent in the control and mutant mice. Anterogradely labeled axons were further characterized as serotonergic (or not), using SERT immunohistochemistry (Fig. $6 D^{\prime}, E^{\prime}$ ).

In the OB of WT mice, anterogradely labeled axons, all of which were SERT ${ }^{+}$, were restricted to the granular cell layer (GCL) and appeared to be arrested at the edge of the mitral cell layer (ML) that expresses high ephrinA5 levels (Fig. 6C); only a few fibers entered into the external plexiform layer (EPL; Fig. $6 D, D^{\prime}$ ), confirming previous observations (Steinfeld et al. 2015; Muzerelle et al. 2016). In the ephrinA5 KO mice, DR axons did not seem to be arrested by the ML, which they crossed, arborizing into the EPL (Fig. $6 E, E^{\prime}$ ). To obtain quantitative measures normalized to the number of anterogradely labeled axons, we estimated the density of TdTomato-labeled fibers in the CGL and EPL and calculated the EPL/CGL 


\section{A}

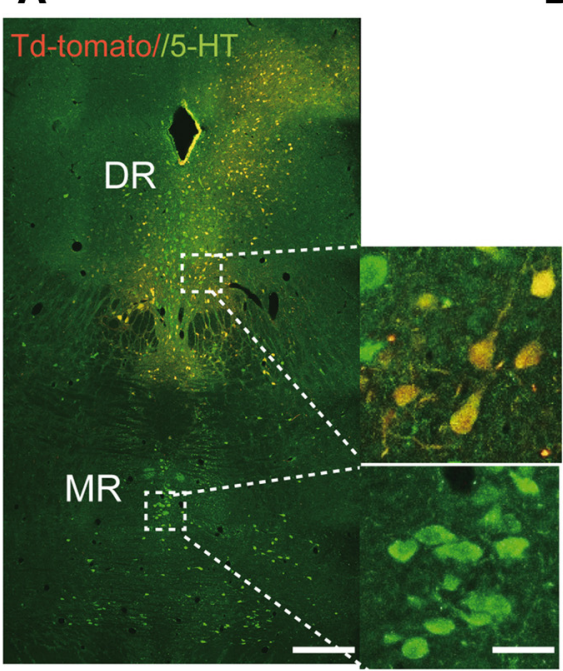

Control
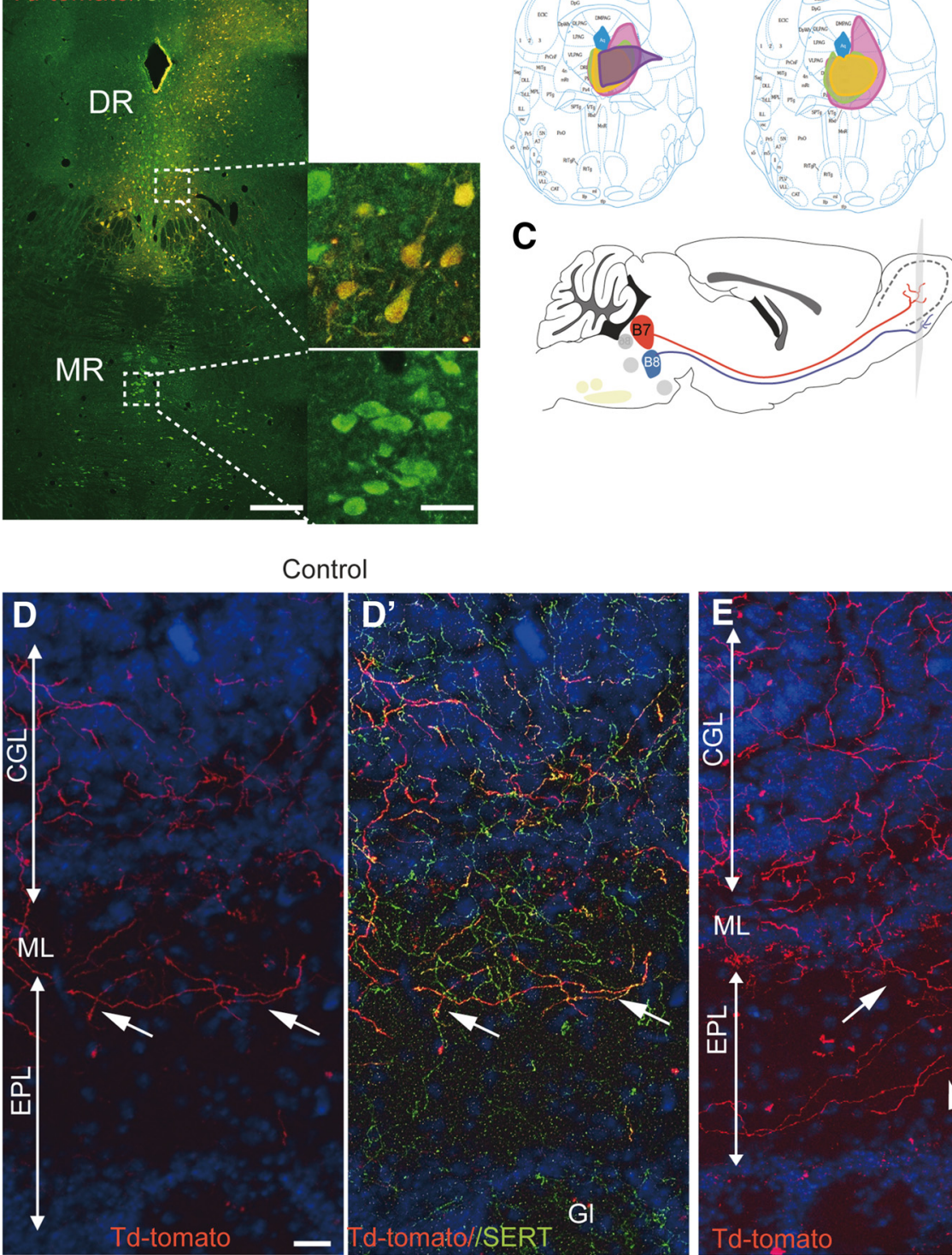

$C^{\prime}$

Efna5-HIS-P5

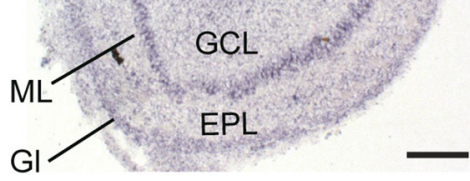

Efna5 KO

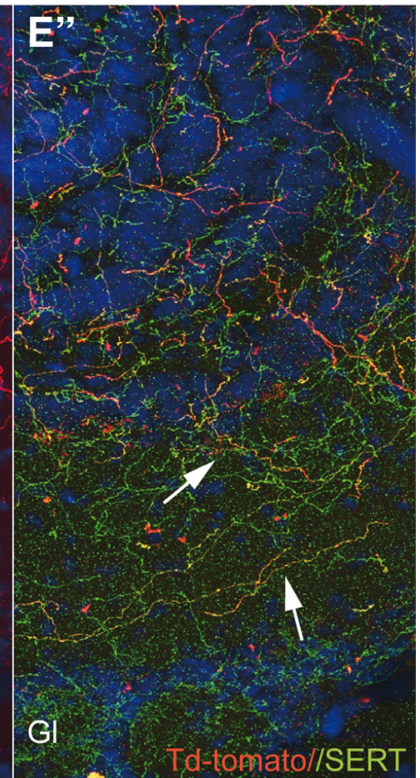

$\mathbf{F}$

G Fiber density-SERT (EPL)

H Fiber density-SERT (GCL)
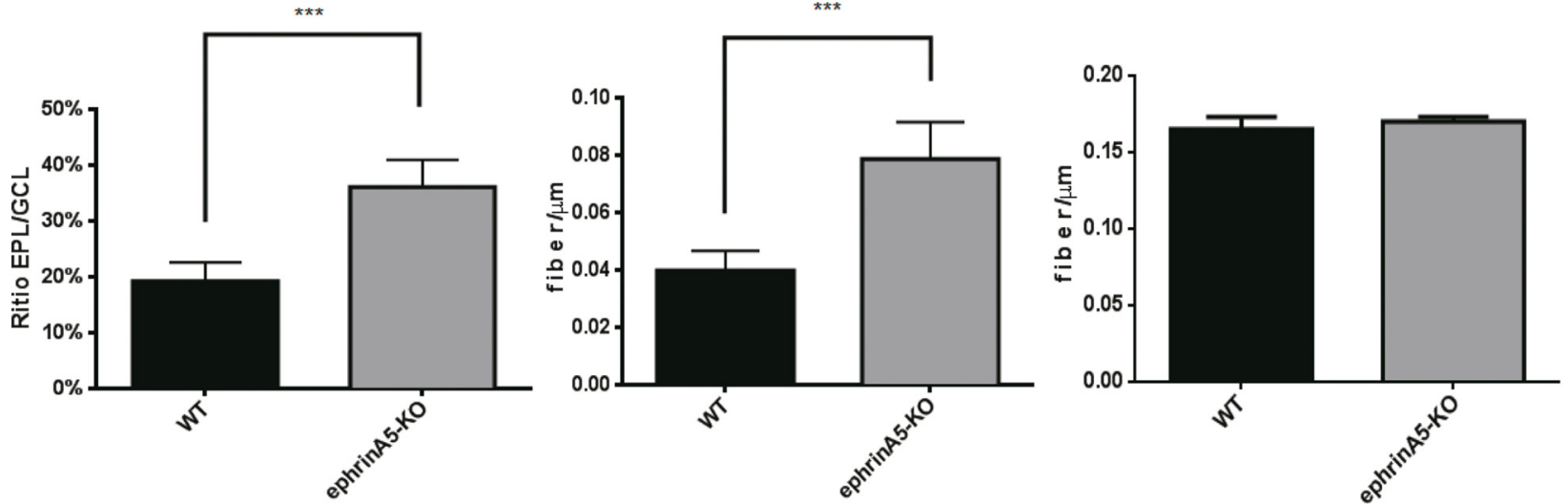

Fig. 6. Anterograde tracing from dorsal raphe to olfactory bulb in ephrinA5 $5^{-1-}$ mice. $\boldsymbol{A}, \mathrm{AAV}-\mathrm{TdTomato}$ virus was injected in the DR. Injection sites were checked with 5-HT immunohistochemistry on the coronal raphe sections, showing 5-HT and TdTomato labeling 
continued

in the DR but not in the MnR $(\boldsymbol{A})$. Scale bar $=500 \mu \mathrm{m}$ (left), $50 \mu \mathrm{m}$ (right). $\boldsymbol{B}$, Scheme shows the extent of AAV transfection in the WT $(n=5)$ and ephrinA5 $(n=5)$ cases; the injection site was reconstructed for each case and drawn manually on representative coronal raphe sections (bregma: $-4.60 \mathrm{~mm}$ ) using a different color code for each case. $\boldsymbol{C}$, Sagittal mouse brain scheme showing the projections from the DR and MnR to the olfactory bulb (OB) targeting the inner (GCL) or outer (GL) layers, respectively. $\boldsymbol{C}^{\prime}$, In situ hybridization of ephrinA5 (Efna5) mRNA on OB coronal section. A selective expression of ephrinA5 is observed in the mitral layer (ML). Scale bar $=250 \mu \mathrm{m}$. $\boldsymbol{D}-\boldsymbol{E}^{\prime}$, Anterogradely labeled axons (TdTomato) and SERT ${ }^{+}$fibers in the OB of WT ( $\boldsymbol{D}$, $\left.\boldsymbol{D}^{\prime}\right)$ and ephrinA5 KO mice $\left(\boldsymbol{E}, \boldsymbol{E}^{\prime}\right)$. Most of the TdTomato were colabeled with SERT. More colabeled fibers were detected in the EPL of ephrinA5 ${ }^{-/-}$mice, compared with WT. Scale bar $=50 \mu \mathrm{m}$. $\boldsymbol{F}-\boldsymbol{H}$, Histograms show the fiber densities of anterogradely labeled and SERT-labeled axons. $\boldsymbol{F}$, The density of TdTomato fibers was normalized by calculating the EPL/GCL fiber density ratio. The density of 5-HT axons was measured as linear density of SERT-labeled axons (fibers/ $\mu \mathrm{m})$ in the EPL (G) and CGL $(\boldsymbol{H} ; * * * p<0.005)$.

ratio. This ratio was significantly increased in ephrinA5 $\mathrm{KO}$ mice compared with WT mice (Fig. 6F). To determine whether the overall density of 5-HT-labeled axons was modified, we measured the density of SERT-labeled axons in the CGL and EPL and found an overall increase in the density of 5-HT axons in the EPL but not in the CGL (Fig. 6G, H). This indicates that the increased EPL/CGL ratio in ephrinA5 $\mathrm{KO}$ mice is not the consequence of a general increase in the number of 5-HT axons reaching the $\mathrm{OB}$, but rather an increase in the fraction of DR axons that cross beyond the ML.

In the same cases, we further analyzed DR anterograde labeling and global 5-HT innervation in two hypothalamic areas that show high ephrinA5 expression: the VMH (Fig. 7A) and the SCN (Fig. 7F). Both nuclei show a high level of ephrinA5 at P5 (Fig. 7A, F). In WT mice, anterograde labeling from the DR showed that neither the $\mathrm{VMH}$ nor the SCN was targeted by DR axons (Fig. 7B', $G^{\prime}$ ), confirming previous observations (Bang et al. 2012; Muzerelle et al., 2016). However, these areas contained a very high density of SERT-labeled terminals that originate mainly from the MnR. In the ephrinA5 KO mice, the density of DR anterograde projection was substantially increased in both the VMH (Fig. $7 C^{\prime}, E$ ) and the SCN (Fig. $7 H^{\prime}, J$ ). Double labeling (TdTomato and SERT) showed that both 5-HT and non-5-HT DR axons contributed to this increase (Fig. $7 C^{\prime \prime}, H^{\prime \prime}$ ). However the overall density of SERTlabeled fibers also showed a significant increase in the VMH (Fig. 7E, I).

These experiments indicated a requirement of ephrinA5 for the targeting of DR axons, showing that the absence of ephrinA5 results in an increased serotonergic innervation of distinctive layers of the $\mathrm{OB}$ and of key hypothalamic nuclei, resulting in an overall increase of the 5-HT innervation in these areas (Fig. 8).

\section{Discussion}

Our results demonstrate for the first time a role of ephrinA signaling for the selective targeting of serotonergic raphe nuclei. We show that EphA5 is differentially expressed across the different hindbrain raphe nuclei, and that this correlates with a different repulsive action of ephrinA on 5-HT axon growth. Ectopic expression of ephrinA inhibits the ingrowth of 5-HT raphe axons in main targets of the dorsal raphe 5-HT neurons, and ephrinA5 loss of function causes a mistargeting of dorsal raphe 5-HT axons, resulting in localized increases in 5-HT innervation.
The development of raphe neurons has been well outlined by classic morphological studies in rodents (Lidov and Molliver, 1982; Wallace and Lauder, 1983); however, few insights have been obtained to date into the molecular control of axon guidance in this system. Wnt signals have been implicated in the polarity of $5-\mathrm{HT}$ neurons (Fenstermaker et al., 2010), and Slit/Robo signaling influences 5-HT axon tract organization in the medial forebrain bundle (Bagri et al., 2002), but hardly anything is known about the molecular control of selective 5-HT axon targeting. This knowledge gap is likely due to a prevailing view of 5-HT neurons as a diffuse, highly collateralized system with limited specificity (Agnati et al., 2006). However, increasing evidence shows that raphe 5-HT neurons are in fact heterogeneous in their molecular identities (Wylie et al., 2010; Okaty et al., 2015; Fernandez et al., 2016), physiology (Calizo et al., 2011; Fernandez et al., 2016), genetic determinants (Jensen et al. 2008; Kiyasova et al., 2011), and connectivity (Azmitia and Segal, 1978; Commons, 2015; Muzerelle et al., 2016). In addition to the established divergence of axons arising from the rostral and caudal 5-HT neuron clusters (directed toward the forebrain and the spinal cord, respectively), there is a distinct topographic organization within the ascending forebrain projections as 5-HT axons originating from the $\mathrm{DR}$ and MnR occupy complementary terminal territories in the forebrain (Bobillier et al., 1976; Azmitia and Segal, 1978; Jacobs et al., 1978; Vertes et al., 1999; Muzerelle et al., 2016). Coinciding with this topographic anatomical organization, our study revealed a gradient of EphA5 gene expression, with higher EphA expression in the DR than in the $\mathrm{MnR}$, and in addition a clear rostral-to-caudal and medial-to-lateral expression gradient. Thus, high EphA5 expression in DR neuronal subsets could explain why DR 5-HT neurons do not innervate brain areas that have high expression of ephrinA, and that these areas are instead innervated by $5-\mathrm{HT}$ neurons from the $\mathrm{MnR}$. This is particularly clear in the case of the $\mathrm{OB}$, where $\mathrm{DR}$ and $\mathrm{MnR}$ 5-HT neurons are located respectively in the central (GCL) or outer (EPL, GL) layers of the OB (Steinfeld et al 2015; Muzerelle et al., 2016). The ephrinA3/5-expressing mitral cell layer might then act as a barrier to prevent DR 5-HT axons from crossing into the outer OB layers. Similarly, hypothalamic nuclei that normally receive all (suprachiasmatic) or a majority (VMH) of their 5-HT innervation from the MnR (Bang et al., 2012; Muzerelle et al., 2016) show high levels of ephrinA expression during development. 
Efna5 HIS-P5
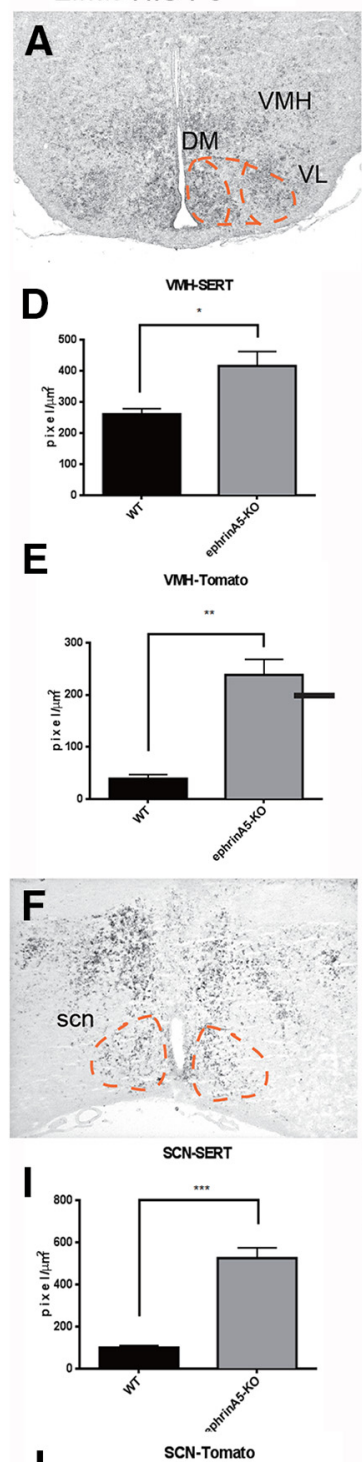

J

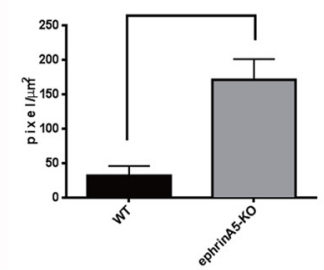

WT-Adult
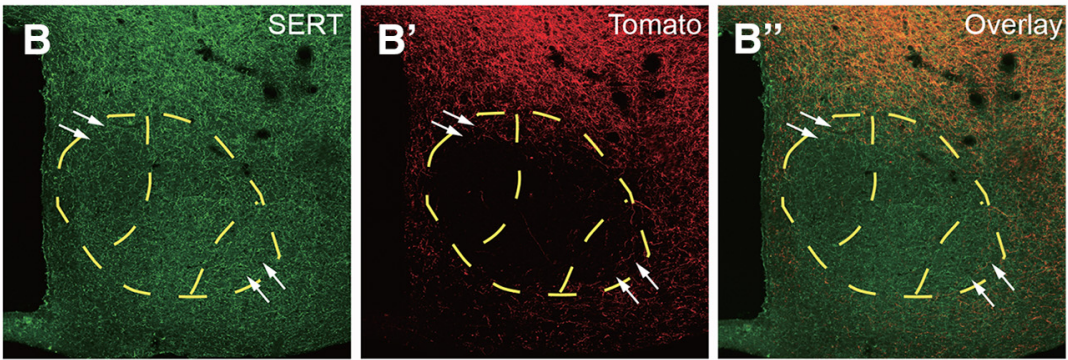

Efna5 Ko-Adult
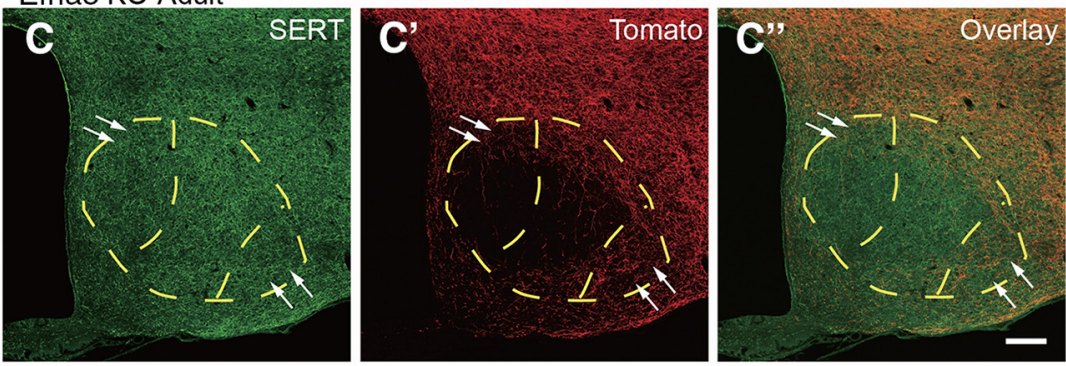

WT-Adult
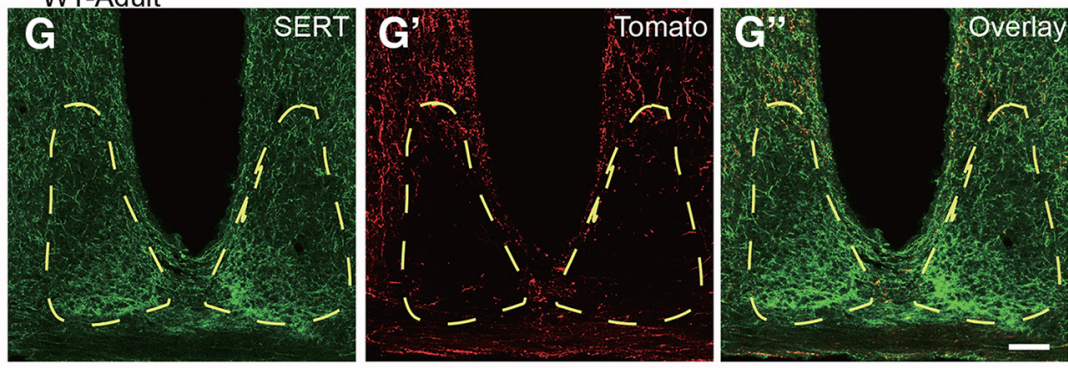

Efna5 KO-Adult
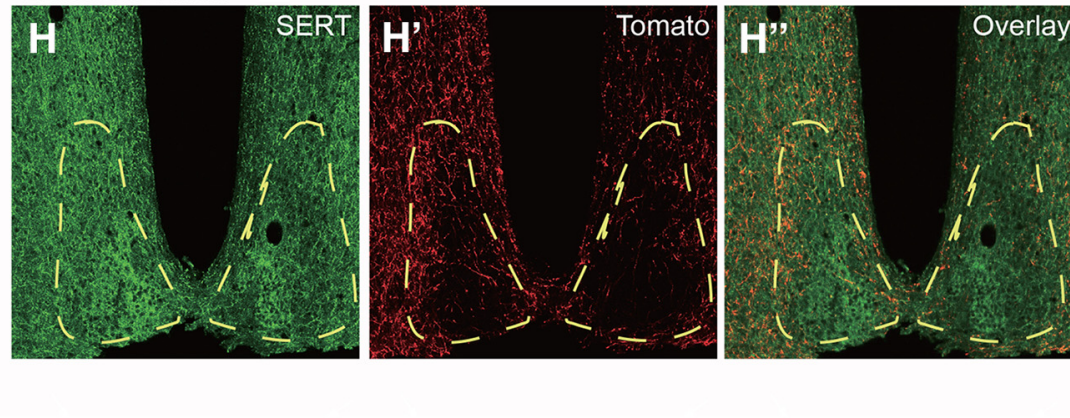

Fig. 7. EphrinA5 expression modulates DR innervation in forebrain target. $\boldsymbol{A}, \boldsymbol{F}$, Expression of ephrinA5 (Efna5) in the ventromedial hypothalamus $(\mathrm{VMH} ; \boldsymbol{A})$, and the suprachiasmatic nucleus $(\mathrm{SCN} ; \boldsymbol{F})$ in coronal brain section of P5 mice. High levels of ephrinA5 were detected in the VL and DM part of VMH. Scale bar $=500 \mu \mathrm{m} . \boldsymbol{B}-\boldsymbol{B}^{\prime \prime}, \boldsymbol{C}-\boldsymbol{C}^{\prime \prime}, \boldsymbol{G}-\boldsymbol{G}^{\prime \prime}, \boldsymbol{H}-\boldsymbol{H}^{\prime \prime}$, Immunofluorescence images show SERT labeling and anterograde labeling of DR in adult in control $\left(\boldsymbol{B}-\boldsymbol{B}^{\prime \prime}, \mathbf{G}-\mathbf{G}^{\prime \prime}\right)$ and ephrinA5 $\mathrm{KO}\left(\boldsymbol{C}-\mathbf{C}^{\prime \prime}, \boldsymbol{H}-\boldsymbol{H}^{\prime \prime}\right)$ mice. Few fibers were detected in $\mathrm{VMH}$ and SCN of the control cases, whereas labeled fibers were detected in larger amounts in the VMH and SCN of the ephrinA5 $\mathrm{KO}$ (see arrows to compare between pictures). Scale bar $=100 \mu \mathrm{m}\left(\boldsymbol{B}-\boldsymbol{C}^{\prime \prime}\right), 50 \mu \mathrm{m}\left(\boldsymbol{G}-\boldsymbol{H}^{\prime \prime}\right) . \boldsymbol{D}, \boldsymbol{E}, \boldsymbol{I}, \boldsymbol{J}$, Histograms show fiber densities anterogradely labeled and SERT ${ }^{+}$axons. Fiber density was calculated as pixels per square micrometer, and data are presented as mean \pm SEM. Unpaired $t$ test, $* p<0.05, * * p<0.01$, and $* * * p<0.005$.

The implication of ephrinA was supported by altered distribution of DR axons. In both the OB and the hypothalamus, 5-HT innervation was increased and anterogradely labeled axons from the DR were misplaced as though an inhibitory barrier was removed. Conversely, when an eph-
rinA ligand was ectopically expressed in a structure such as the amygdala, which is a preferential target of the DR 5-HT innervation (Muzerelle et al., 2016), the ingrowth of $5-\mathrm{HT}$ raphe axons was significantly reduced. Thus, present results indicate that ephrinA5 signaling contributes to 


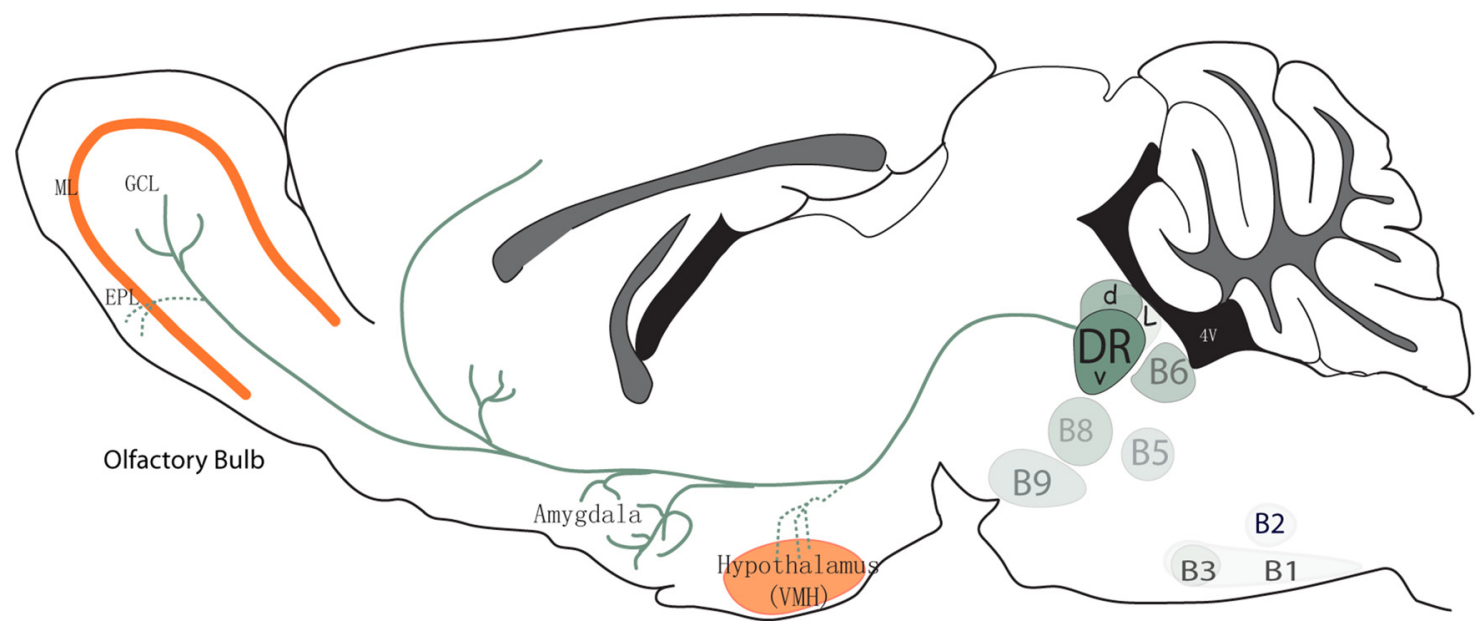

Fig. 8. Summary diagram. This scheme shows the expression level of EphA5 in the different 5-HT raphe nuclei, indicated with different shades of green, the maximal being in the DR-V, and lowest in B1, B2. The projections of the DR 5-HT neurons to the amygdala and to the granular cell layer (GCL) of the olfactory bulb are indicated with solid lines. In the ephrinA5 knockout mice, additional projections to the ventromedial hypothalamus $(\mathrm{VMH})$ and the external plexiform layer (EPL) are visible, indicated with dotted lines. High ephrinA5-expression in the mitral cell layer (ML) and $\mathrm{VMH}$ is indicated in orange.

the selective targeting of 5-HT axons in the forebrain by repelling the ingrowth of $5-\mathrm{HT}$ axons originating from the $\mathrm{DR}$, in brain regions that are normally targeted by the MnR.

EphrinA signaling may also influence other aspects of the topography of DR; this is suggested by our observation of a difference of EphA5 expression in the medial lateral parts of the DR, which coincides with differential anatomical projections. 5- HT neurons in the lateral wings of the DR with low level of EphA expression project to regions with high ephrinA5 expression such as the lateral geniculate nucleus (Wilks et al. 2010; Muzerelle et al. 2016). It will be interesting to determine in the future how the combination of axon guidance molecules in raphe targets contributes to attracting subsets of 5-HT axons to defined brain areas/layers. In particular, we do not know what factors attract the MnR 5-HT axons to the areas that are avoided by the DR. Intriguingly $5-\mathrm{HT}$ itself could contribute to the growth-promoting effects, since a defective innervation of the SCN was observed in Tph2-KO mice (Migliarini et al., 2013). The mistargeting of DR axons in the hypothalamus of ephrinA5 KO mice concerned both 5-HT and non-5-HT neurons of the DR; indeed, as noted in the present study, both cell types express EphA5. These common axon guidance cues are consistent with shared connectivity profiles: previous anatomical tracing studies showed that DR afferents frequently contain a mix of 5-HT and non-5-HT neurons (Steinbusch and Nieuwenhuys, 1981; Kiyasova et al., 2011); the latter could include glutamatergic Vglut $^{+}$(Hioki et al., 2010) and GABAergic neurons (Bang et al., 2012). Thus DR neurons could share similar axon guidance mechanisms, independent of their neurotransmitter content.

EphA-ephrinA signaling is involved in several neuronal developmental processes from cell migration to synaptic maturation (Cooper et al. 2009; Cramer and Miko, 2016; Kania and Klein, 2016), although its best-known implication in neural development is for axon guidance, where both repulsive and attractive interactions have been described. Our current studies indicated a main inhibitory effect of the ephrinA ligands on 5-HT axon growth: in vitro, ephrinA5 induced a collapse of the growth cones, and in vivo ectopic expression of ephrinA3 inhibited 5-HT axon ingrowth. This corresponds to the classic repulsive forward signaling of EphA receptor activation (Kania and Klein, 2016) and is most likely due to the EphA5 receptor according to the present localization studies. However, we cannot exclude the implication of other EphAs, since transcriptional profiling of raphe neurons in embryonic and postnatal brains also reported the presence of other EphA (Wylie et al., 2010; Okaty et al., 2015), but likely expression is at levels that are too low for our ISH detection. Moreover, the loose specificity of the EphA5 receptors for ephrinA ligands and the redundancy of ephrinA expression in several brain targets (such as the mitral cells in the $\mathrm{OB}$ ) suggest that the defects of 5- $\mathrm{HT}$ axon targeting observed in the ephrinA5 $\mathrm{KO}$ might be more pronounced in double or triple ephrinA KO mice. Such redundancy has previously been shown in the visual system (Feldheim et al., 2000).

In the visual and auditory sensory maps, Eph-ephrinA signaling acts to build a continuous topographic map (Cramer and Miko, 2016); however, present results do not indicate that this is the case in the $5-\mathrm{HT}$ raphe system, where topography is much looser. Indeed, DR and MnR have different targets but do not display further topographic organization within their preferred targets. Thus, we propose that as regards the 5-HT systems, EphephrinA signaling could act in a target selection process, by generating nonpermissive boundaries for the ingrowth of DR 5-HT raphe subtypes. This effect would then be more similar to that observed for the motor neurons when choosing dorsal/ventral muscle targets during development (Eberhart et al., 2004).

EphA5 expression in 5-HT raphe neurons was dynamically expressed, being maximal during axon growth in 
embryonic life, reaching target during the early postnatal period, and showing decreased expression, similarly to what has reported for ephrinA5 expression (Deschamps et al., 2010). Given the potential of 5-HT neurons to regenerate and grow, it will be interesting to know whether the present developmental mechanisms are reactivated after a lesion, and whether the propensity of serotonin axons to regrow (Müllner et al., 2008) is linked to their EphA content.

What could be the pathophysiological consequences of targeting defects of raphe neurons in the olfactory bulb or the hypothalamus? Our observations in ephrinA5 $\mathrm{KO}$ showed that mistargeting of the DR axons was correlated with a general increase of 5-HT innervation in these regions, suggesting that excitatory/inhibitory balance is compromised in these brain nuclei. Interestingly, behavioral observations conducted in ephrinA5 and EphA5 KO mice showed some phenotypes that could relate to our observations. These studies report a reduction in intermale aggression (Mamiya et al., 2008; Sheleg et al., 2015), and an increase of 5-HT levels in the hypothalamus (Mamiya et al., 2008), consistent with our observations of increased 5-HT innervation in this brain region. Interestingly, the increased 5-HT innervation that we found in the ephrinA5 $\mathrm{KO}$ was concentrated in the ventrolateral part (VMHVL), which is implicated in modulating aggression (Martinez et al 2008; Silva et al. 2016). Clearly, the pathophysiological consequences of SCN hyperinnervation calls for further studies on the circadian rhythms in these mutants, given the implication of 5-HT innervation to the SCN in entraining circadian rhythmicity (Versteeg et al., 2015)

Given the implication of 5-HT in a wide range of behaviors and psychiatric disorders, our study points to new gene targets that may indirectly affect 5-HT functions by changing the targeting of raphe neurons and inducing modifications of 5-HT inputs in selected brain regions.

\section{References}

Agnati LF, Leo G, Zanardi A, Genedani S, Rivera A, Fuxe K, Guidolin D (2006) Volume transmission and wiring transmission from cellular to molecular networks: history and perspectives. Acta Physiol 187:329-344. CrossRef

Azmitia EC, Segal M (1978) An autoradiographic analysis of the differential ascending projections of the dorsal and median raphe nuclei in the rat. J Comp Neur 179:641-667. CrossRef Medline

Bagri A, Marín O, Plump AS, Mak J, Pleasure SJ, Rubenstein JL, Tessier-Lavigne M (2002) Slit proteins prevent midline crossing and determine the dorsoventral position of major axonal pathways in the mammalian forebrain. Neuron 33:233-248. Medline

Bang SJ, Jensen P, Dymecki SM, Commons KG (2012) Projections and interconnections of genetically defined serotonin neurons in mice. Eur J Neurosci 35:85-96. CrossRef Medline

Bobillier P, Seguin S, Petitjean F, Salvert D, Touret M, Jouvet M (1976) The raphe nuclei of the cat brain stem: a topographical atlas of their efferent projections as revealed by autoradiography. Brain Res 113:449-486. Medline

Brust RD, Corcoran AE, Richerson GB, Nattie E, Dymecki SM (2014) Functional and developmental identification of a molecular subtype of brain serotonergic neuron specialized to regulate breathing dynamics. Cell Rep 9:2152-2165. CrossRef Medline

Calizo LH, Akanwa A, Ma X, Pan YZ, Lemos JC, Craige C, Heemstra LA, Beck SG (2011) Raphe serotonin neurons are not homoge- nous: electrophysiological, morphological and neurochemical evidence. Neuropharmacology 61:524-543. CrossRef

Commons KG (2015) Two major network domains in the dorsal raphe nucleus. J Comp Neur 523:1488-1504. CrossRef Medline

Cooper MA, Kobayashi K, Zhou R (2009) Ephrin-A5 regulates the formation of the ascending midbrain dopaminergic pathways. Dev Neurobiol 69:36-46. CrossRef Medline

Cramer KS, Miko IJ (2016) Eph-ephrin signaling in nervous system development. F1000Research 5. CrossRef

Deakin JF, Graeff FG (1991) 5-HT and mechanisms of defence. J Psychopharmacol 5:305-315. CrossRef

Deschamps C, Faideau M, Jaber M, Gaillard A, Prestoz L (2009) Expression of ephrinA5 during development and potential involvement in the guidance of the mesostriatal pathway. Exp Neurol 219:466-480. CrossRef Medline

Deschamps C, Morel M, Janet T, Page G, Jaber M, Gaillard A, Prestoz L (2010) EphrinA5 protein distribution in the developing mouse brain. BMC Neurosci 11:105. CrossRef Medline

Eberhart J, Barr J, O'Connell S, Flagg A, Swartz ME, Cramer KS, Tosney KW, Pasquale EB, Krull CE (2004) Ephrin-A5 exerts positive or inhibitory effects on distinct subsets of EphA4-positive motor neurons. J Neurosci 24:1070-1078. CrossRef Medline

Feldheim DA, Kim YI, Bergemann AD, Frisén J, Barbacid M, Flanagan JG (2000) Genetic analysis of ephrin-A2 and ephrin-A5 shows their requirement in multiple aspects of retinocollicular mapping. Neuron 25:563-574. Medline

Fenstermaker AG, Prasad AA, Bechara A, Adolfs Y, Tissir F, Goffinet A, Zou Y, Pasterkamp RJ (2010) Wnt/planar cell polarity signaling controls the anterior-posterior organization of monoaminergic axons in the brainstem. J Neurosci 30:16053-16064. CrossRef

Fernandez SP, Cauli B, Cabezas C, Muzerelle A, Poncer JC, Gaspar P (2016) Multiscale single-cell analysis reveals unique phenotypes of raphe 5-HT neurons projecting to the forebrain. Brain Struct Function 221:4007-4025. CrossRef Medline

Frisén J, Yates PA, McLaughlin T, Friedman GC, O'Leary DD, Barbacid M (1998) Ephrin-A5 (AL-1/RAGS) is essential for proper retinal axon guidance and topographic mapping in the mammalian visual system. Neuron 20:235-243. Medline

Gale N. W., Holland S. J., Valenzuela D. M., Flenniken A., Pan L., Ryan T. E. et al. (1996). Eph receptors and ligands comprise two major specificity subclasses and are reciprocally compartmentalized during embryogenesis. Neuron 17(1), 9-19. CrossRef

Gerstmann K, Pensold D, Symmank J, Khundadze M, Hübner CA, Bolz J, Zimmer G (2015) Thalamic afferents influence cortical progenitors via ephrin A5-EphA4 interactions. Development 142: 140-150. CrossRef Medline

Hale MW, Lowry CA (2011) Functional topography of midbrain and pontine serotonergic systems: implications for synaptic regulation of serotonergic circuits. Psychopharmacology 213:243-264. CrossRef Medline

Hioki H, Nakamura H, Ma YF, Konno M, Hayakawa T, Nakamura KC, Fujiyama F, Kaneko T (2010) Vesicular glutamate transporter 3 -expressing nonserotonergic projection neurons constitute a subregion in the rat midbrain raphe nuclei. J Comp Neur 518:668686. CrossRef Medline

Huang TN, Chuang HC, Chou WH, Chen CY, Wang HF, Chou SJ, Hsueh YP (2014) Tbr1 haploinsufficiency impairs amygdalar axonal projections and results in cognitive abnormality. Nat Neurosci 17:240-247. CrossRef Medline

Jacobs BL, Azmitia EC (1992) Structure and function of the brain serotonin system. Physiol Rev 72:165-229. Medline

Jacobs BL, Foote SL, Bloom FE (1978) Differential projections of neurons within the dorsal raphe nucleus of the rat: a horseradish peroxidase (HRP) study. Brain Res 147:149-153. Medline

Jensen P, Farago AF, Awatramani RB, Scott MM, Deneris ES, Dymecki SM (2008) Redefining the serotonergic system by genetic lineage. Nat Neurosci 11:417-419. CrossRef Medline

Kania A, Klein R (2016) Mechanisms of ephrin-Eph signalling in development, physiology and disease. Nat Rev Mol Cell Biol 17: 240-256. CrossRef Medline 
Kiyasova V, Gaspar P (2011) Development of raphe serotonin neurons from specification to guidance. Eur J Neurosci 34:1553-1562. CrossRef Medline

Kiyasova V, Fernandez SP, Laine J, Stankoversuski L, Muzerelle A, Doly S, Gaspar P (2011) A genetically defined morphologically and functionally unique subset of $5-\mathrm{HT}$ neurons in the mouse raphe nuclei. J Neurosci 31:2756-2768. CrossRef

Klein R., \& Kania A. (2014) Ephrin signalling in the developing nervous system. Curr Opin Neurobiol 27, 16-24.

Lidov HG, Molliver ME (1982) Immunohistochemical study of the development of serotonergic neurons in the rat CNS. Brain Res Bull 9:559-604. Medline

Lucki I (1998) The spectrum of behaviors influenced by serotonin. Biol Psychiatr 44:151-162. Medline

Mamiya PC, Hennesy Z, Zhou R, Wagner GC (2008) Changes in attack behavior and activity in EphA5 knockout mice. Brain Res 1205:91-99. CrossRef Medline

Martinez RCR, Carvalho-Netto EF, Amaral VCS, Nunes-de-Souza RL, Canteras NS (2008) Investigation of the hypothalamic defensive system in the mouse. Behav Brain Res 192:185-190. CrossRef

Migliarini S, Pacini G, Pelosi B, Lunardi G, Pasqualetti M (2013) Lack of brain serotonin affects postnatal development and serotonergic neuronal circuitry formation. Mol Psychiatr 18:1106-1118. CrossRef Medline

Miko IJ, Nakamura PA, Henkemeyer M, Cramer KS (2007) Auditory brainstem neural activation patterns are altered in EphA4- and ephrin-B2-deficient mice. J Comp Neur 505:669-681. CrossRef Medline

Müllner A, Gonzenbach RR, Weinmann O, Schnell L, Liebscher T, Schwab ME (2008) Lamina-specific restoration of serotonergic projections after Nogo-A antibody treatment of spinal cord injury in rats. Eur J Neurosci 27:326-333. CrossRef Medline

Muzerelle A, Scotto-Lomassese S, Bernard JF, Soiza-Reilly M, Gaspar $P$ (2016) Conditional anterograde tracing reveals distinct targeting of individual serotonin cell groups (B5-B9) to the forebrain and brainstem. Brain Struct Function 221:535-561. CrossRef Medline

Nguyen T, Chin WC, O'Brien JA, Verdugo P, Berger AJ (2001) Intracellular pathways regulating ciliary beating of rat brain ependymal cells. J Physiol 531:131-140. CrossRef.

O'Leary DD, Wilkinson DG (1999) Eph receptors and ephrins in neural development. Curr Opin Neurobiol 9:65-73.

Okaty BW, Freret ME, Rood BD, Brust RD, Hennessy ML, deBairos D, Kim JC, Cook MN, Dymecki SM (2015) Multi-scale molecular deconstruction of the serotonin neuron system. Neuron 88:774791. CrossRef Medline

Pflieger JF, Clarac F, Vinay L (2002) Postural modifications and neuronal excitability changes induced by a short-term serotonin depletion during neonatal development in the rat. $\mathrm{J}$ Neurosci 22:5108-5117.

Prakash N, Vanderhaeghen P, Cohen-Cory S, Frisen J, Flanagan JG, Frostig RD (2000) Malformation of the functional organization of somatosensory cortex in adult ephrin-A5 knock-out mice revealed by in vivo functional imaging. J Neurosci 20:5841-5847.
Prestoz L, Jaber M, Gaillard A (2012) Dopaminergic axon guidance: which makes what? Frontiers Cell Neurosci 6:32. CrossRef Medline

Remedios R, Subramanian L, Tole S (2004) LIM genes parcellate the embryonic amygdala and regulate its development. J Neurosci 24:6986-6990. CrossRef

Schmidt BJ, Jordan LM (2000) The role of serotonin in reflex modulation and locomotor rhythm production in the mammalian spinal cord. Brain Res Bull 53:689-710. Medline

Scott MM, Wylie CJ, Lerch JK, Murphy R, Lobur K, Herlitze S, Jiang W, Conlon RA, Strowbridge BW, Deneris ES (2005) A genetic approach to access serotonin neurons for in vivo and in vitro studies. Proc Natl Acad Sci U S A 102:16472-16477. CrossRef Medline

Sheleg M, Yochum CL, Richardson JR, Wagner GC, Zhou R (2015) Ephrin-A5 regulates inter-male aggression in mice. Behav Brain Res 286:300-307. CrossRef Medline

Sousa VH, Miyoshi G, Hjerling-Leffler J, Karayannis T, Fishell G (2009) Characterization of Nkx6-2-derived neocortical interneuron lineages. Cereb Cortex 19(Suppl 1):1-10. CrossRef

Silva BA, Mattucci C, Krzywkowski P, Cuozzo R, Carbonari L, Gross CT (2016) The ventromedial hypothalamus mediates predator fear memory. Eur J Neurosci 43:1431-1439. CrossRef Medline

Steinbusch HW, Nieuwenhuys R (1981) Localization of serotonin-like immunoreactivity in the central nervous system and pituitary of the rat, with special references to the innervation of the hypothalamus. Adv Exp Med Biol 133:7-35. Medline

Steinfeld R, Herb JT, Sprengel R, Schaefer AT, Fukunaga I (2015) Divergent innervation of the olfactory bulb by distinct raphe nuclei. J Comp Neur 523:805-813. CrossRef Medline

Teissier A, Chemiakine A, Inbar B, Bagchi S, Ray RS, Palmiter RD, Dymecki SM, Moore H, Ansorge MS (2015) Activity of raphé serotonergic neurons controls emotional behaviors. Cell Reports 13:1965-1976. CrossRef Medline

Trowbridge S, Narboux-Nême N, Gaspar P (2011) Genetic models of serotonin $(5-\mathrm{HT})$ depletion: what do they tell us about the developmental role of 5-HT? Anat Rec 294:1615-1623. CrossRef Medline

Versteeg RI, Serlie MJ, Kalsbeek A, la Fleur SE (2015) Serotonin, a possible intermediate between disturbed circadian rhythms and metabolic disease. Neuroscience 301:155-167. CrossRef Medline

Vertes RP, Fortin WJ, Crane AM (1999) Projections of the median raphe nucleus in the rat. J Comp Neur 407:555-582. Medline

Wallace JA, Lauder JM (1983) Development of the serotonergic system in the rat embryo: an immunocytochemical study. Brain Res Bull 10:459-479. Medline

Wilks TA, Rodger J, Harvey AR (2010) A role for ephrin-As in maintaining topographic organization in register across interconnected central visual pathways. Eur J Neurosci 31:613-622. CrossRef Medline

Wylie CJ, Hendricks TJ, Zhang B, Wang L, Lu P, Leahy P, Fox S, Maeno H, Deneris ES (2010) Distinct transcriptomes define rostral and caudal serotonin neurons. J Neurosci 30:670-684. CrossRef 